\title{
Assessment of polar organic aerosols at a regional background site in southern Africa
}

\section{Booyens, Wanda}

2019-06

Booyens , W , Beukes , J P , Van Zyl, P G , Ruiz-Jimenez , J , Kopperi , M , Riekkola , M-L , Josipovic, M , Vakkari , V \& Laakso, L 2019 , ' Assessment of polar organic aerosols at a regional background site in southern Africa ' , Journal of Atmospheric Chemistry , vol. 76 , no. 2 , pp. 89-113 . https://doi.org/10.1007/s10874-019-09389-y

http://hdl.handle.net/10138/321641

https://doi.org/10.1007/s10874-019-09389-y

acceptedVersion

Downloaded from Helda, University of Helsinki institutional repository.

This is an electronic reprint of the original article.

This reprint may differ from the original in pagination and typographic detail.

Please cite the original version. 


\section{Assessment of polar organic aerosols at a regional background site in 2 southern Africa}

3

4

Wanda Booyens ${ }^{1}$, Johan P. Beukes ${ }^{1}$, Pieter G. Van Zyl ${ }^{1 *}$, Jose Ruiz-Jimenez ${ }^{2}$, Matias Kopperi², Marja-Liisa Riekkola², Miroslav Josipovic ${ }^{1}$, Ville Vakkari ${ }^{3}$, Lauri Laakso ${ }^{1,3}$

${ }^{1}$ Unit for Environmental Science and Management, North-West University, Private Bag X6001, 2520, Potchefstroom, South Africa

${ }^{2}$ Department of Chemistry, University of Helsinki, PO Box 55, 00014, University of Helsinki, Finland ${ }^{3}$ Finnish Meteorological Institute, PO Box 503, 00101, Helsinki, Finland

* Corresponding author: Pieter G. van Zyl, e-mail: pieter.vanzyl@nwu.ac.za, tel: +27 (0) 18299 2353, fax: +27 (0) 182992350 .

\section{Abstract}

A recent paper reported GCxGC-TOFMS analysis used for the first time in southern Africa to tentatively characterise and semi-quantify $~ 1000$ organic compounds in aerosols at Welgegund - a regional background atmospheric monitoring station. Ambient polar organic aerosols characterised are further explored in terms of temporal variations, as well as the influence of meteorology and sources. No distinct seasonal pattern was observed for the total number of polar organic compounds tentatively characterised and their corresponding semi-quantified concentrations (sum of the normalised response factors, $\sum$ NRFs). However, the total number of polar organic compounds and $\sum$ NRFs between late spring and early autumn seemed relatively lower compared to the period from mid-autumn to mid-winter, while there was a period during late winter and early spring with significantly lower total number of polar organic compounds and $\sum$ NRFs. Relatively lower total number of polar organic compounds and corresponding $\sum$ NRFs were associated with fresher plumes from a source region relatively close to Welgegund. Meteorological parameters indicated that wet 
removal during late spring to early autumn also contributed to lower total numbers of polar organics and associated $\sum$ NRFs. Increased anticyclonic recirculation and more pronounced inversion layers contributed to higher total numbers of polar organic species and $\sum$ NRFs from mid-autumn to midwinter, while the influence of regional biomass burning during this period was also evident. The period with significantly lower total number of polar organic compounds and $\sum$ NRFs was attributed to fresh open biomass burning plumes occurring within proximity of Welgegund, consisting mainly of volatile organic compounds and non-polar hydrocarbons. Multiple linear regression substantiated that the temporal variations in polar organic compounds were related to a combination of the factors investigated in this study.

Keywords: particulate matter; organic compounds; Welgegund; GCxGC-TOFMS; biomass burning; multiple linear regression

\section{Introduction}

Southern Africa is considered to be a significant source of atmospheric pollutants, which include atmospheric gaseous species and aerosols species. South Africa has the largest industrialised economy in Africa, with a large number of mining, industrial and agricultural activities (Lourens et al. 2011; Laakso et al. 2012). In addition, biomass burning is also a significant source of atmospheric pollutants in the region through the prevalent occurrence of household combustion for space heating and cooking (Wichmann and Voyi 2006; Venter et al. 2012; South Africa Environmental Outlook 2012), as well as the widespread incidences of wild fires (Alade 2010; Vakkari et al. 2014; Strydom and Savage 2016). The influence of biomass burning plumes from southern Africa on South America and Australia is well documented (Swap et al. 2003). There has been a substantial increase in atmospheric measurements in southern Africa during the last few years through various endeavours, which include legislative compliance monitoring by government and industries (Collett et al. 2010; Pretorius et al. 2016), as well as through numerous scientific initiatives and programmes (Kulmala et al. 2011; Laakso et al. 2012; Venter et al. 2012; Tiitta et al. 2014; Conradie et al. 2016). However, the 
region is still considered to be understudied with regard to atmospheric measurements (Laakso et al. 2012), especially relating to the characterisation of atmospheric aerosols (Booyens et al. 2015).

Atmospheric aerosols or particulate matter (PM) are directly emitted from various natural (e.g. wind-blown dust, wild fires) and anthropogenic (e.g. incomplete fossil fuel combustion, household biomass burning) sources. In addition, atmospheric aerosols are also formed through chemical reactions and physical processes in the atmosphere. It is important to chemically and physically characterise PM, since the influence of these species on air quality and climate is determined by their physical and chemical properties. Some species, such as sulphate $\left(\mathrm{SO}_{4}{ }^{2-}\right)$ and certain organic compounds, for instance, scatter incoming solar radiation that has a cooling effect on the atmosphere, while absorbing compounds, such as black carbon (BC), have a warming effect on the atmosphere. Atmospheric aerosols are frequently classified according to their aerodynamic diameters (size) as coarse $\mathrm{PM}_{10}$ (particles $\left.\leq 10 \mu \mathrm{m}\right)$, fine $\mathrm{PM}_{2.5}$ (particles $\left.\leq 2.5 \mu \mathrm{m}\right)$ and ultra-fine $\mathrm{PM}_{0.1}$ (particles $\leq 0.1$ $\mu \mathrm{m})$ and $\mathrm{PM}_{1}$ (particles $\leq 1 \mu \mathrm{m}$ ) particulates, which is important with regard to the impact of these species on human health. Larger $\mathrm{PM}_{10}$ species are usually filtered in the nose and throat, while smaller $\mathrm{PM}_{2.5}, \mathrm{PM}_{1}$ and $\mathrm{PM}_{0.1}$ particulates penetrate through the respiratory system and affect other organs (Pope and Burnett 2002).

Atmospheric aerosols comprise a large number of inorganic and organic compounds. It has been indicated that the organic content of atmospheric aerosols can range between 20 and $90 \%$ of the total PM in the atmosphere (Jimenez et al. 2009). Tiitta et al. (2014) recently indicated that a large fraction $(\approx 50 \%)$ of chemical species identified in aerosols at a regional background site in South Africa, i.e. Welgegund, were organic compounds. Furthermore, Vakkari et al. (2015) also indicated the importance of organic compounds in the growth of newly formed particles measured at Welgegund, while Chiloane et al. (2017) indicated that organic aerosols comprise a significant fraction of aerosol measurements conducted in the north-eastern interior of South Africa, where major anthropogenic sources in South Africa are located. This organic fraction of atmospheric aerosols consists of thousands of organic compounds with different chemical and physical properties (Goldstein and Galbally 2007). However, current organic compound measurements, e.g. aerosol mass spectrometry (AMS), provide limited insight into the actual chemical species, and the present 
1 knowledge on the chemical composition of atmospheric organic compounds is incomplete (Ruiz-

2 Jimenez et al. 2011). Therefore, observations with more precise speciation are needed. One such

method entails the characterisation of organic atmospheric aerosols with comprehensive twodimensional gas chromatography coupled with a time-of-flight mass spectrometer (GCxGC-TOFMS) (Lewis et al. 2000, Welthagen et al. 2003, Alam et al. 2013, Booyens et al. 2015), which is a powerful instrument for the chemical characterisation of organic compounds in complex matrices.

Booyens et al. (2015) recently utilised GCxGC-TOFMS for the first time in South Africa to tentatively identify and semi-quantify 1056 ambient organic compounds in aerosols collected on filters for three different size fractions ( $\mathrm{PM}_{1}, \mathrm{PM}_{2.5-1}$ and $\left.\mathrm{PM}_{10-2.5}\right)$ at a regional background site, i.e. Welgegund. This was considered to be the largest number of ambient organic compounds tentatively characterised in atmospheric samples utilising GCxGC-TOFMS. Furthermore, the ambient aerosol samples collected were also the most comprehensive number of size-resolved ambient atmospheric aerosol samples collected in southern Africa for the characterisation of organic compounds. The organic compounds characterised were categorised according to their functional groups as oxygenated, hydrocarbons, halogenated compounds, N-containing compounds and S-containing compounds, while it was indicated that oxygenated species were the most abundant. Although Booyens et al., (2015) expanded extensively on the characteristics of the comprehensive dataset, the dataset was not explored explicitly in terms of temporal variations in organic aerosol composition, as well as the influence of meteorological conditions and specific sources on organic aerosol composition. Therefore, the aim of this paper was to conduct an assessment of ambient organic aerosol compounds characterised at Welgegund in view of possible temporal variability associated with the influence of meteorological conditions, as well as major sources and source regions impacting air masses measured at Welgegund. Furthermore, organic aerosols in southern Africa are affected by globally important sources, which include (primary and secondary) biomass burning aerosols (and secondary organic aerosols in general) (Vakkari et al. 2014; Tiitta et al. 2014). In addition, since Booyens et al. (2015) indicated that the polar solvent extraction mixture utilised was not validated for non-polar species, which could have contributed to lower values related to the 
number of hydrocarbon species tentatively characterised and their associated semi-quantified concentrations, only ambient polar organic aerosols were considered.

\section{Measurement location and methods}

\subsection{Site description and meteorological conditions}

The Welgegund monitoring station (www.welgegund.org) is a comprehensively equipped atmospheric measurement site located within the South African Highveld approximately $100 \mathrm{~km}$ west of Johannesburg on a commercial farm (latitude 26³4'10"S, longitude 2656'21"E, 1480 m AMSL)

(Fig. 1). Welgegund is considered to be a regionally representative background site with no direct impacts from large pollution sources in close proximity. It is, however, impacted by plumes passing over the major anthropogenic source regions in the interior of South Africa, which include the Western Bushveld Igneous Complex (WBIC), the Eastern Bushveld Igneous Complex (EBIC), the Johannesburg-Pretoria metropolitan conurbation, the Vaal Triangle and the Mpumalanga Highveld, as well as a region of anticyclonic circulation of air mass over the interior of South Africa as indicated in Fig. 1. The western sector (from north-west to south-east) contains no significant point sources, which can therefore be considered as representative of a relatively clean regional background (Fig. 1). The impacts of widespread regional wild fires that mainly occur during the dry winters and early spring are also observed at Welgegund (Vakkari et al. 2014). A number of papers have been published on atmospheric measurements conducted at Welgegund, wherein detailed descriptions of measurements conducted (Petäjä et al. 2013; Beukes et al. 2015; Räsänen et al. 2016), geographical and bioregion location (Booyens et al. 2015; Jaars et al. 2016), and the major source regions affecting Welgegund (Beukes et al. 2013; Jaars et al. 2014) have been presented.

\section{Insert Fig. 1}

Laakso et al. (2012) with references therein presented a synopsis of meteorological conditions prevalent over the South African Highveld, which was summarised by Booyens et al. (2015). In short, anti-cyclonic circulation dominates the atmospheric circulation path over the South African Highveld, 
especially during the winter months (June to August). During winter and early spring, multiple inversion layers form on a regular basis at various altitudes, which significantly reduce the vertical mixing of atmospheric pollutant species and lead to significant increases in the concentrations of atmospheric pollutants (Hobbs et al. 2003; Vakkari et al. 2014; Giannakaki et al. 2016). The South African Highveld is also characterised by distinct wet and dry seasons with the wet season generally occurring from middle October to April. Wet scavenging during the wet season contributes to lower concentrations of atmospheric pollutants, while levels of atmospheric species increase during the cold and dry season due to large-scale open biomass burning (Vakkari et al., 2014), as well as increased household combustion for space heating and cooking (Vakkari et al., 2014). The average temperature measured at Welgegund during the sampling period was $18{ }^{\circ} \mathrm{C}$, ranging between -3 and $28{ }^{\circ} \mathrm{C}$ in the winter, and 10 and $33^{\circ} \mathrm{C}$ in summer.

\subsection{Sample collection and analysis}

Detailed descriptions of the sample collection, analysis, and quality control and -assurance procedures are presented by Booyens et al. (2015). In short, 24-hour ambient aerosol samples in three size ranges, i.e. $\mathrm{PM}_{1}, \mathrm{PM}_{2.5-1}$ and $\mathrm{PM}_{10-2.5}$ were collected on quartz filters once a week from 12 April 2011 until 4 April 2012 with a Dekati $\mathrm{PM}_{10}$ cascade impactor at a flow rate of $30 \mathrm{~L} / \mathrm{min}$. The mean volume of air sampled was 46023 L ranging between 50223 and 29599 L. A polar solvent mixture of methanol and acetone utilising dynamic ultrasonic-assisted extraction was used to extract samples from filters, after which three to four drops of toluene were added, the extracts dried with a gentle nitrogen stream and reconstituted with $5 \mathrm{ml}$ methanol. Three separate aliquots $(1 \mathrm{ml})$ from each sample were further pre-concentrated and an internal standard (1-1'binaphthyl) was added. The first aliquot was directly analysed, while the other two aliquots were derivatised in order to transform nonvolatile compounds into volatile compounds. Analysis was performed with a LECO Pegasus 4D GCxGC-TOFMS system equipped with an Agilent 7890 A GC and an Agilent 7683 B auto sampler. The GCxGC-TOFMS method utilised was based on the method developed by Ruiz-Jimenez et al. (2011B), i.e. a two-separation column setup providing primary volatility-based separation, followed by secondary polarity-based separation. 


\subsection{Characterisation and semi-quantification}

Detailed descriptions of characterisation and semi-quantification methods performed are presented by Booyens et al. (2015). To summarise, certain procedures and rules were applied in order to optimise the number of compounds identified and to increase the reliability of organic compounds characterised. Organic compounds were identified through mass spectral matching of deconvoluted peaks in the NIST library (normal and reverse spectral similarity fit $\geq 700$ ), while the automated comparison of experimental and theoretical retention indices (I) (difference of 150 units between experimental and literature $I$ values) was also performed. Additional organic compounds not included in the NIST library were identified with the Golm metabolome database, which contains mass spectral data for biologically active metabolites (Hummel et al. 2010). Compounds characterised are considered to be tentatively identified organic species due to the less restrictive positive characterisation parameters applied as indicated in Booyens et al. (2015). Polar compounds characterised include oxygenated species (alcohols, ethers, aldehydes, ketones, carboxylic acids, esters), halogenated compounds ( $\mathrm{Cl}, \mathrm{Br}, \mathrm{I}, \mathrm{F})$, as well as nitrogen (N)- and sulphur (S)-containing organic compounds. The concentrations of the organic compounds tentatively characterised were expressed as response factors (RF) in relation to the internal standard, i.e. 1-1'binaphthyl, which was also used by Ruiz-Jimenez et al. (2011A) and Ruiz-Jimenez et al. (2011B) to semi-quantify polar and non-polar organic compounds. The RFs for the different polar organic compounds were calculated in relation to the internal standard, i.e. peak area of the compound $\left(A_{c i}\right) /$ peak area of the internal standard $\left(A_{\mathrm{IS}}\right)$. The RFs were also normalised per volume of air sampled (V), i.e. RF/V, which is presented as the sum of the normalised RFs ( $\left.\sum \mathrm{NRF}\right)$.

\subsection{Air mass history analysis}

Back trajectories were calculated with the HYSPLIT (HYbrid Single-Particle Langrangian Integrated Trajectory) model (version 4.8), which was developed by the National Oceanic and Atmospheric Administration (NOAA) Air Resources Laboratory (ARL) (Stein et al. 2015). The model runs with meteorological data from the Global Data Assimilation System (GDAS) archive of 
the US National Weather Service's National Centre for Environmental Prediction (NCEP), which is archived by the ARL. For each 24-hour sampling period, individual hourly arriving 96-hour (4 days) back trajectories were calculated at an arrival height of $100 \mathrm{~m}$.

\subsection{Ancillary measurements}

The numbers of polar organic compounds tentatively characterised and semi-quantified were related to temperature (T) and relative humidity (RH) (Rotronic MP 101A), as well as soil moisture measured at different depths (5 and $20 \mathrm{~cm}$ ) with a Theta probe ML2x (Delta-T) at Welgegund. Additional soil moisture information was obtained with a $100 \mathrm{~cm}$ PR2 soil moisture profile probe (Delta-T).

\section{Results}

\subsection{Temporal variations}

In Fig. 2, the total numbers of polar organic compounds tentatively identified and their corresponding $\sum \mathrm{NRF}$ in the three size ranges for each sample collected during the entire sampling period are presented. From Fig. 2, it is evident that although the total number of polar organic compounds tentatively characterised and the $\sum$ NRFs were different for each of the samples collected, no distinct seasonal pattern for the total number of polar organic compounds and their semi-quantified concentrations is observed. Small differences in the total number of polar organic compounds tentatively characterised and the $\sum \mathrm{NRF}$ s could be attributed to different sample volumes. However, the sample volumes recorded for each 24-hour sample collected remained relatively constant throughout the sampling period. There is, however, a period from 2 August 2011 to 4 October 2011, coinciding with austral winter and spring, during which total number of polar organic compounds and corresponding $\sum$ NRFs were significantly lower. In addition, it also seems that the $\sum$ NRFs were more consistent and relatively higher during the sampling period 12 April 2011 to 12 July 2011 compared to the sampling period between 11 October 2011 and 4 April 2012, while the total number of polar organic compounds were also lower during the latter period. The averages of the total number of polar compounds and their associated $\sum$ NRFs calculated for these three periods are listed in Table 1. 
1 During the period 2 August 2011 to 4 October 2011 the average total number of polar organic

2 compounds and $\sum$ NRFs were $35 \pm 12$ and $270 \pm 185$, respectively, while the average total number of 3 polar organic compounds and $\sum$ NRFs were $278 \pm 58$ and $4769 \pm 777$, respectively for the sampling period 12 April 2011 to 12 July 2011. These differences between the total number of polar organic compounds and the $\Sigma$ NRFs for these two periods are considered to be statistically significant with 80 and $90 \%$ probabilities, respectively according to the t-test (Skoog et al., 2014). The average of the total number of polar species and the $\Sigma$ NRFs for the period from 11 October 2011 to 4 April 2012 were $115 \pm 36$ and $2938 \pm 1870$, respectively. The t-test indicate less statistically significant differences for this period in comparison to the period from 2 August 2011 to 4 October 2011, i.e. $50 \%$ probabilities for the total number of organic compounds and the $\Sigma$ NRFs, which is attributed to the large pooled standard deviation when comparing these two periods. Although the t-test do no indicate statistically significant differences for the averages of the total number of polar compounds and the $\Sigma$ NRFs for the periods from 12 April 2011 to 12 July 2011 and 11 October 2011 to 4 April 2012, the average of the total number of polar species and the $\Sigma$ NRFs are higher for the period from 12 April 2011 to 12 July 2011 than that of the 11 October 2011 to 4 April 2012 period. These occurrences will be explored in subsequent sections in this paper. Furthermore, in most instances with exception of a few outliers, the size distribution in each of the samples also resembled the combined total size distribution for all the samples collected indicated by Booyens et al. (2015), with no very large differences ( $>\sim 10 \%$ ) between the total number of organic compounds tentatively identified in the three size fractions, while relatively higher $\sum$ NRFs of the species tentatively identified were determined in the $\mathrm{PM}_{2.5-1}$ size fraction.

\section{Insert Fig. 2}

\section{Insert Table 1}

In Fig. 3, the total numbers of oxygenated species, (a) halogenated compounds, (b) as well as $\mathrm{N}$ - (c) and S-containing (d) organic compounds tentatively identified with their corresponding $\sum \mathrm{NRF}$ in the three size ranges for each sample collected are presented. Booyens et al. (2015) indicated that 
oxygenated species were the most abundant species ( $\sim 5 \%$ of the $\sum$ NRFs), which is reflected by each of the samples collected. Similar to the total number of polar organic compounds tentatively characterised and their associated $\sum$ NRFs determined in the different size ranges in each sample (Fig. 2), no distinct temporal variations are observed for the total number of species tentatively characterised for each functional group and their corresponding $\sum$ NRFs. However, the total numbers of species tentatively characterised for each of the functional groups and their corresponding $\sum$ NRFs do reflect the period between 2 August 2011 and 4 October 2011 with substantially lower total numbers of species and corresponding $\sum \mathrm{NRF}$, as well as relatively higher total numbers of polar compounds and corresponding $\sum$ NRFs for the sampling period 12 April 2011 to 12 July 2011 compared to the sampling period between 11 October 2011 and 4 April 2012. Also indicated in Table 1 are the averages of the total number of species and corresponding $\sum$ NRFs calculated for each of the functional groups for the three periods identified. According to the t-test differences in the average $\sum$ NRFs of oxygenated species, halogenated compounds and N-containing species determined for the 2 August 2011 to 4 October 2011 and 12 April 2011 to 12 July 2011 periods were statistically significant (70\%, 70\% and 60\% probabilities, respectively), while the differences of the averages of the total number of oxygenated species and $\mathrm{N}$-containing compounds for these two periods were also statistically significant ( $80 \%$ and $60 \%$ probabilities, respectively). Similarly to the total number of polar species and their respective $\sum$ NRFs, less statistically significant differences are determined for the averages of the total number of species and $\sum$ NRFs when relating the 2 August 2011 to 4 October 2011 period to the 11 October 2011 to 4 April 2012 period for oxygenated species, halogenated compounds and $\mathrm{N}$-containing species, which is in most instances also attributed to the large pooled standard deviations. The t-test also indicate no statistically significant differences for the averages of the periods from 12 April 2011 to 12 July 2011 and 11 October 2011 to 4 April 2012 for oxygenated species, halogenated compounds and N-containing species. However, the averages of the total number and the $\Sigma$ NRFs of each of these classes of compounds are higher for the period from 12 April 2011 to 12 July 2011 compared to that of the 11 October 2011 to 4 April 2012 period. The averages of the small number of S-containing compounds and their associated $\sum$ NRFs are statistically considered to 
1 be in the same range for all three periods, although the total number and $\sum$ NRFs were also higher for 2 the 12 April 2011 to 12 July 2011.

3

\section{Insert Fig. 3}

\subsection{Elucidation of temporal variations}

In an effort to explain the temporal variations observed for the polar organic compounds, as well as the occurrence of significantly lower total number of polar organic compounds and corresponding $\sum$ NRFs determined for the sampling period from 2 August 2011 to 4 October 2011, the influences of different source regions impacting Welgegund, meteorological conditions, and fire counts over the interior of southern Africa were explored.

\subsubsection{Source region influence}

Beukes et al. (2013) classified the major source regions impacting Welgegund according to air mass history as the regional background, Western Bushveld Igneous Complex, the JohannesburgPretoria megacity, the Vaal Triangle, the Mpumalanga Highveld and the combined Anticyclonic Recirculation-Eastern Bushveld Igneous Complex. However, since only 24-hour ambient aerosol samples were collected once a week, the allocation of hourly back trajectories to air masses passing over all of these source regions defined by Beukes et al. (2013) was not feasible. Therefore, similar to Jaars et al. (2014), the Johannesburg-Pretoria megacity, the Vaal Triangle and the Mpumalanga Highveld source regions, which were identified as the regions with the highest anthropogenic impacts, were grouped together and are referred to as Area A in this paper. The Western and Eastern Bushveld Igneous Complex, as well as the anti-cyclonic source regions that lie on the anti-cyclonic recirculation path of air masses moving towards Welgegund (Fig. 1), were grouped together, which are referred to as Area B. The regional background source region was kept as defined by Beukes et al. (2013), referred to as Area C. In Fig. 1, the different source regions considered in this paper are presented. It is also evident from Fig. 1 that the major large point sources in Area A include coal-fired power 
stations and petrochemical plants, while pyrometallurgical smelters are major large point sources in Area B.

In total, 1248 (52 samples $\times 24$ hours) back trajectories were generated for the entire sampling period. Back trajectories were classified as passing over the different source regions defined in Fig. 1. Only back trajectories that had passed over one of the defined source regions were considered. Therefore, back trajectories that had passed over both anthropogenic source regions (Areas A and B) were not considered, while back trajectories were allocated as passing over the regional background (Area C) if such trajectories did not pass over either Area A or B, or both Area A and B. According to these criteria, $69 \%$ of all back trajectories could be classified as passing over just one of the three source regions defined. The back trajectories of air masses passing over the different source region are presented in Fig. 4. $19 \%$ of the air mass back trajectories could be classified as passing over Area A, while $27 \%$ and $23 \%$ of the air mass back trajectories could be classified as passing over Area B and Area C, respectively, for the entire sampling period. The reason for the lower percentage of air masses passing over Area A can be attributed to the persistence of the anti-cyclonic circulation pattern over the interior of South Africa, which favours the arrival of air masses at Welgegund from the north to north-eastern sector.

\section{Insert Fig. 4}

In Fig. 5, the percentages of hourly arriving air masses passing over the different source regions during each 24-hour sampling period are presented. The influence of source regions on the total number of polar organic compounds and the corresponding $\sum$ NRFs is not that evident. However, in section 3.1, we indicated that it seems that $\sum$ NRFs were more consistent and relatively higher during the sampling period 12 April 2011 to 12 July 2011 compared to the sampling period 11 October 2011 to 4 April 2012, while the total numbers of polar organic compounds were also lower during the latter period. A comparison of the percentage of hourly arriving air masses passing over the different source regions for the sampling period between 12 April 2011 and 12 July 2011 and the sampling period 
between 11 October 2011 and 4 April 2012 does indicate a few more instances of air masses passing over Region A between 11 October 2011 and 4 April 2012.

\section{Insert Fig. 5}

In Fig. 6, the total number of organic compounds and the corresponding $\sum N R F$ s measured for air masses passing over the three source regions are presented. It is evident that the total number of polar organic compounds and the corresponding $\sum$ NRFs were the highest in air masses passing over Area B, second highest for Area C and the lowest for air masses passing over Area A, which were between 20 and $40 \%$ lower than the total number of polar organic compounds and the corresponding $\sum$ NRFs determined for Area B. The higher number of organic compounds and their associated higher concentrations associated with Area B can be attributed to the aging of air masses during the anticyclonic recirculation of primary emissions. Booyens et al. (2015) indicated that the highest number of organic compounds with the highest corresponding $\sum$ NRFs were oxygenated species that were considered to be indicative of secondary organic aerosol formation occurring in aged air masses influencing Welgegund. The relatively high concentrations of polar organic compounds in Area C, i.e. the regional background can also be attributed to secondary aerosol formation from natural emissions of VOCs, as well as to smaller cities and agricultural activities in this region. Furthermore, Welgegund is also affected by regional biomass burning events (Vakkari et al. 2014), and it was indicated that oxygenated organic particulates measured with an aerosol chemical specification monitor (ACSM) correlated with biomass burning aerosols during the dry season (Tiitta et al. 2014). This will be further explored in a subsequent section.

The lower number of polar organic compounds with their corresponding $\sum$ NRFs in Area A can be attributed to fresher plumes from Area A arriving at Welgegund. Jaars et al. (2014) indicated that the highest aromatic VOC concentrations were associated with this source region, which was attributed to anthropogenic emissions in this region. Lourens et al. (2012) indicated that the Johannesburg-Pretoria megacity is relatively heavily polluted, while both the Vaal Triangle and the Mpumalanga Highveld source regions have been included in areas declared as pollution hotspots 
1 (national priority areas) by the South African government (Government Gazette 2005; Government

2 Gazette 2007). However, due to this source region being in close proximity of Welgegund, these

3 primary emitted VOCs have less time to form secondary organic aerosols (Özel et al., 2010). It is also

4 evident from Figs. 2 and 3(a) that during the period characterised by relatively lower $\sum$ NRFs (11

5 October 2011 to 4 April 2012) instances of higher $\sum$ NRFs were associated with higher $\sum$ NRFs of

6 oxygenated species. In addition, higher $\sum$ NRFs during this period were also associated with higher

$7 \quad \sum$ NRFs of halogenated compounds (Fig. 3(b)), which are also oxidised organic compounds indicative

8 of aged air masses.

9

From the discussion above, the total number of organic compounds and corresponding $\sum$ NRFs for each sample presented in Fig. 2 can partially be attributed to differences in air mass histories. There is, however, no clear connection between the different source regions and the occurrence of a significantly lower total number of polar organic compounds and corresponding $\sum$ NRFs determined for the sampling period from 2 August 2011 to 4 October 2011.

\subsubsection{Meteorological conditions}

As indicated in section 2.1, this region is characterised by distinct wet (middle October to April) and dry (May to middle October) seasons, while multiple inversion layers and anti-cyclonic recirculation are more pronounced during the winter months (June to August). Therefore, in an effort to evaluate the influence of meteorological conditions on the number of organic compounds determined and their corresponding $\sum \mathrm{NRF}$, box-and-whisker plots of the temperature, relative humidity, soil moisture and wind speed for each 24-hour sampling period were compiled, which are presented in Fig. 7. Since one 24-hour sample was collected once a week, precipitation events could not be directly correlated to the number of organic compounds determined and their corresponding $\sum$ NRFs. Therefore, soil moisture and relative humidity were considered to be indicative of precipitation. The meteorological data indicate the typical seasonal patterns for this region, i.e. higher 
temperatures observed for the period between late spring and early autumn, while relative humidity and soil moisture related to the distinct wet and dry seasons. However, wind speed measured during each of the 24-hour sampling periods did not distinctly reflect the seasonality associated with the stability of the boundary layer, i.e. increased stability corresponding to more pronounced inversion layers during winter.

As indicated in sections 3.1 and 3.2.1, the total number of polar organic compounds and the corresponding $\sum$ NRFs were relatively higher during the sampling period 12 April 2011 to 12 July 2011, which coincides with late autumn and early winter. As previously mentioned, the colder months in this region are characterised by more pronounced inversion layers trapping pollutants near the surface, while an increase in emissions occurs due to an increase in household combustion and the occurrence of wild fires. Furthermore, the anti-cyclonic recirculation of air masses is also more pronounced, which could lead to an increase in pollutants from source regions. The sampling period 11 October 2011 to 4 April 2012, which had relatively lower total number of polar organic compounds and corresponding $\sum \mathrm{NRFs}$, coincided with the period between late spring and early autumn, which corresponds with the wet season. Although this period is characterised by higher temperatures, as well as increased relative humidity and soil moisture that can lead to increased biogenic emissions of organic compounds, it seems that the wet scavenging of polar organic particulates is more pronounced during this period. However, there were certain sampling days during this period when higher polar organic compound concentrations were measured, which could be attributed to fewer occurrences of rain events. In addition, lower total number of polar organic compounds and corresponding $\sum \mathrm{NRF}$ associated with higher temperatures, can also be attributed to increased blow-off sampling artifacts at higher temperatures (Geldenhuys et al. 2015). ACSM measurement of $\mathrm{PM}_{1}$ conducted by Tiitta et al. (2014) at Welgegund also indicated lower organic aerosol concentrations during the wet season. Although meteorological conditions do reflect to some extent a seasonal pattern in the total number of polar organic compounds and their corresponding $\sum \mathrm{NRF}$, the observed variances in the total number and $\sum$ NRFs of polar organic compounds can rather be attributed to the combined influence of meteorology and sources as indicated by Tiitta et al. (2014). There is no clear correlation between the meteorological data and the occurrence of 
1 significantly lower total number of organic compounds and corresponding $\sum \mathrm{NRF}$ s determined for the

2 sampling period from 2 August 2011 to 4 October 2011. This period, however, does coincide with the

\section{Insert Fig. 7}

\subsubsection{Fire counts}

In Fig. 8, a map of MODIS burned area observations in southern Africa within a $1000 \mathrm{~km}$ radius of Welgegund for the entire sampling period is presented, which indicates the widespread occurrence of wild fires for this region. Wild fire occurrences are predominant in the sector northwest to south of Welgegund, with significant wild fire occurrences in the eastern part of South Africa. It is evident that wild fires will have a significant impact on air masses arriving at Welgegund. In addition, it is also evident that within close proximity of Welgegund, i.e. a $100 \mathrm{~km}$ radius, wild fires occurring in all directions from Welgegund can have an influence on air masses arriving at Welgegund. In Fig. 9, the monthly numbers of fire counts (fire pixels) within a $1000 \mathrm{~km}$ radius of Welgegund for a five-year period (a), i.e. 2009 to 2013 are presented in order to contextualise the number of fire counts during the sampling period in this study, while the number of fire counts within a $1000 \mathrm{~km}$ radius of Welgegund during each 24-hour sampling period (b) are presented. Fig. 9 clearly indicate a significant number (MODIS fire pixels ranging in the orders of $10^{4}$ and $10^{5}$ ) of wild fires occurring within a $1000 \mathrm{~km}$ radius of Welgegund. From the five-year period, it is evident that these wild fires mainly occur from May to October, which coincides with the dry season. It is also apparent that the number of wild fires peaked in August and September, i.e. the end of winter and beginning of spring, for the five-year period. Therefore, as indicated in section 3.2.1, the widespread occurrence of wild fires can be a significant source of organic compounds measured at Welgegund. Tiitta et al. (2014) also indicated that biomass burning is the most important emission source of organic aerosols in $\mathrm{PM}_{1}$ during the dry season. 


\section{Insert Fig. 8}

\section{Insert Fig. 9}

3

From Fig. 9(b), it is evident that the 2 August 2011 to 4 October 2011 period during which significantly lower total numbers of polar organic compounds and corresponding $\sum$ NRFs were measured (Fig. 2), coincided with the peak burning season months in August and September. There is, in particular, a significantly large number of fire counts observed for the 24-hour sample collected on 23 October 2011, during which the fire counts were more than double the fire counts determined for the other 24-hour samples collected during August and September. This concurrence between the period with significantly lower total number of polar organic compounds and corresponding $\sum \mathrm{NRFs}$, and the peak burning season months alludes to Welgegund being impacted by fresh biomass burning plumes, i.e. wild fires occurring in close proximity of Welgegund. From Fig. 8, it is evident that a large number of wild fires occurred within close proximity of Welgegund (100 km radius,), while Fig. 9(a) also indicates that the numbers of fire counts within a $100 \mathrm{~km}$ radius of Welgegund for July to September in 2011 were significantly higher compared the number of fire counts during these months for the other four year presented in Fig. 9(a). It is expected that fresh biomass burning plumes would be characterised by a smaller number of secondary (oxidised) organic aerosols, since most of the VOCs associated with biomass burning would not have been transformed to secondary organic aerosols. Furthermore, it is also expected that organic aerosol compounds in fresh biomass burning plumes will mainly consist of non-polar hydrocarbon species that have not yet been oxidised to oxygenated-, halogenated-, N-containing or S-containing species (Özel et al. 2010). From Fig. 3(b), it is also evident that, although the corresponding $\sum$ NRFs of halogenated compounds were lower from 2 August 2011 to 4 October 2011, the total number of halogenated compounds was not significantly lower during this period. This can possibly be attributed to the occurrence of potassium chloride $(\mathrm{KCl})$ in the fresh smoke of burning savannah grass, which can react to form halogenated organic compounds (Aurela et al. 2016). Venter et al. (2018) collected inorganic aerosols at Welgegund from 24 November 2010 to December 2011 and attributed increased $\mathrm{Cl}^{-}$concentrations from July to September to the influence of biomass burning. 


\subsubsection{Multiple linear regression}

From the discussions in the previous sections, it seems that the observed temporal variations for the total number of polar organic compounds and their corresponding $\sum$ NRFs cannot be related to a specific single influencing factor, and depend on a combination of the influences of source regions, meteorology and wild fires. Furthermore, none of these factors could conclusively explain the occurrence of significantly lower total number of polar organic compounds and corresponding $\sum$ NRFs determined for the sampling period from 2 August 2011 to 4 October 2011. Therefore, in an effort to quantify the influence of these factors on the total number of polar organic compounds and their associated $\sum \mathrm{NRF}$, multiple linear regression (MLR) was performed as an explorative tool by using the source regions (Region A, Region B and Region C), meteorological parameters (temperature, relative humidity, soil moisture, wind speed) and fire counts as input data in order to indicate parameter interdependencies on the total number of polar organic compounds characterised. In Fig. 10(a), the root mean square error (RMSE) difference between the experimentally characterised and calculated total number of polar organic compounds, as a function of the number of interdependent variables included in the optimum MLR solution, is presented. The interdependence between six parameters resulted in the optimum decrease in RMSE, with soil moisture (as a proxy for precipitation), temperature, fire pixel counts within a $100 \mathrm{~km}$ radius and source region A resulting in more significant decreases in RMSE differences, i.e. the predominant parameters influencing the temporal variations. The measure of optimisation was taken as at least $1 \%$ contribution to the overall reduction of RMSE. In Fig. 10(b), the experimentally characterised total numbers of polar organic compounds are compared to the calculated total numbers of polar organic compounds, which indicate very good correlations between the experimentally characterised and the calculated total numbers of polar organic compounds. Differences between measured and calculated values could partially be ascribed to the exclusion of non-polar hydrocarbons in this study due to the polar extraction solvent utilised. The total number of polar organic compounds calculated from MLR mimics the differences observed for sampling periods identified in sections 3.2.1 to 3.2.3, i.e. 12 April 2011 to 12 July 2011, 2 August 2011 to 4 October 2011 and 11 October 2011 to 4 April 2012. The relatively good correlations for the 2 August 2011 to 4 October 2011 period with significantly lower total number or 
organic compounds, especially, indicate relatively high level of confidence in the statistical evaluation of the total number of polar organic compounds dataset. This statistical analysis substantiates the deductions made in sections 3.2.1 to 3.2.3 where it was indicated that that the total numbers of polar organic compounds and associated semi-quantified concentrations were related to a combination of the influence of source regions, meteorology and the occurrence of wild fires within close proximity of Welgegund. In addition, negative correlations were calculated between the total numbers of polar organic compounds, and temperature, fires within a $100 \mathrm{~km}$ radius and air masses passing over source region $\mathrm{A}$, which agree with the deductions made in sections 3.2.1 to 3.2.3. Lower total numbers of polar organic compounds were associated with air masses passing over source regions A, higher temperatures (late spring to mid-autumn) and increases in wild fires occurring within close proximity of Welgegund.

\section{Insert Fig. 10}

\section{Summary and conclusions}

No distinct seasonal pattern was observed for the polar organic compounds tentatively characterised and their corresponding $\sum$ NRFs (semi-quantified concentrations), as well as for the total number of species tentatively characterised for each of the functional groups and their corresponding $\sum$ NRFs. However, there was a period coinciding with late winter and early spring with a significantly lower total number of polar organic compounds and corresponding $\sum$ NRFs, while it also seemed that the total numbers of polar organic compounds and their associated $\sum$ NRFs for the period coinciding with mid-autumn to mid-winter were relatively higher compared to the period from late spring to midautumn. Therefore, in an effort to elucidate the temporal variations, the influences of source regions, meteorology and burnt area pixels were investigated. Three source regions were identified, which indicated that the relatively lower total number of polar organic compounds and corresponding $\sum$ NRFs could be attributed to fresher plumes arriving at Welgegund from a source region comprising the Johannesburg-Pretoria megacity, the Vaal Triangle and the Mpumalanga Highveld, while relatively higher total numbers of organic compounds and the corresponding $\sum$ NRFs were associated 
1 with aged air masses passing over the other source region and the regional background.

2 Meteorological parameters indicated that the wet removal of aerosols contributed to lower total numbers of polar organic compounds and corresponding $\sum$ NRFs, while increased anticyclonic recirculation and more pronounced inversion and stable stratified layers in winter contributed to the pollution entrapment and consequently higher total number of polar organic compounds and the corresponding $\sum$ NRFs. Fire counts indicated large-scale biomass burning as an important source of polar organic aerosol compounds. The period with a significantly lower total number of organic compounds and corresponding $\sum \mathrm{NRF}$, which coincided with the peak burning months, was attributed to the influence of wild fires in close proximity of Welgegund. Fresher biomass burning plumes impacting Welgegund would mainly contain primary emitted VOCs and non-polar hydrocarbon aerosols.

Since the temporal variations observed could not be related to a specific influencing factor, but rather seemed to depend on a combination of the influences of source regions, meteorology and fire counts, MLR analysis was performed in in an effort to quantify the influence of each of these factors on the total number of polar organic compounds and corresponding $\sum$ NRFs. Furthermore, none of these factors could conclusively explain the period with a significantly lower total number of organic compounds and corresponding $\sum$ NRFs. MLR indicated that that the total numbers of polar organic compounds and associated semi-quantified concentrations were related to a combination of the influence of source regions, meteorology and the occurrence of wild fires within close proximity of Welgegund.

\section{Acknowledgements}

The authors wish to acknowledge Diederik and Jackie Hattingh and their family who are the owners of the commercial farm on which the Welgegund measurement station is situated. V. Vakkari is a beneficiary of an AXA Research Fund postdoctoral grant. 


\section{References}

Alade, O. L.: Characteristics of particulate matter over the South African industrialized Highveld. University of the Witwatersrand: Dissertation MSc. (2010)

Alam, M. S., West, C. E., Scarlett, A. G., Rowland, S. J., Harrison, R. M.: Application of 2D-GCMS reveals many industrial chemicals in airborne particulate matter. Atmos. Environ. 65, 101-111 (2013)

Aurela, M., Beukes, J. P., Van Zyl, P. G., Vakkari, V., Teinilä, K., Saarikoski, S., Laakso, L.: The composition of ambient and fresh biomass burning aerosols at a savannah site, South Africa. S. Afr. J. Sci. 112 (5/6), Art. \#2015-0223, 8 pages (2016). http://dx.doi.org/10.17159/ sajs.2016/20150223

Beukes, J. P., Vakkari, V., Van Zyl, P. G., Venter, A. D., Josipovic, M., Jaars, K., Tiitta, P., Kulmala, M., Worsnop, D., Pienaar, J.J., Virkkula, A., Laakso, L.: Source region plume characterisation of the interior of South Africa as observed at Welgegund. Clean Air Journal, 23(1), 7-10 (2013)

Beukes, J. P., Venter, A. D., Josipovic, M., Van Zyl, P. G., Vakkari, V., Jaars, K., Dunn, M., Laakso, L.: Automated Continuous Air Monitoring. In: Forbes, P., (eds.) Monitoring of air pollutants Samling, sample, preparation and analytical techniques, Volume 70, pp. 183-208. Elsevier (2015) doi: 10.1016/bs.coac.2015.09.006. ISBN: 9780444635532

Booyens, W., Van Zyl, P.G., Beukes, J.P., Ruiz-Jimenez, J., Kopperi, M., Riekkola, M.-L., Josipovic, M., Venter, A.D., et al., Jaars, K., Laakso, L., Vakkari, V., Kulmala, M., Pienaar, J.J.: Sizeresolved characterisation of organic compounds in atmospheric aerosols collected at Welgegund, South Africa. J. Atmos. Chem. 72, 43-64 (2015)

Chiloane, K.E., Beukes, J.P., Van Zyl, P.G., Maritz, P., Vakkari, V., Josipovic, M., Venter, A.D., Jaars, K., Tiitta, P., Kulmala, M., Wiedensohler, A., Liousse, C., Mkhatshwa, G.V., Ramandh, A. and Laakso, L.: Spatial, temporal and source contribution assessments of BC over the northern interior of South Africa. Atmos. Chem. Phys. 17, 6177-6196 (2017). doi:10.5194/acp17-6177-2017.

Collett, K. S., Piketh, S. J. \& Ross, K. E. (2010). An assessment of the atmospheric nitrogen budget on the South African Highveld. S. Afr. J. Sci., 106(5/6). 
1 Conradie, E.H., Van Zyl, P.G., Pienaar, J.J., Beukes, J.P., Galy-Lacaux, C., Venter, A.D. and

2

3 Mkhatshwa, G.V.: The chemical composition and fluxes of atmospheric wet deposition at four sites in South Africa. Atmos. Environ. 146, 113-131 (2016). http://dx.doi.org/10.1016/j.atmosenv.2016.07.033

Geldenhuys, G., Rohwer, E. R., Naudé, Y., Forbes, P. B. C.: Monitoring of atmospheric gaseous and particulate polycyclic aromatic hydrocarbons in South African platinum mines utilising portable denuder sampling with analysis by thermal desorption-comprehensive gas chromatography-mass spectrometry. J. Chromatogr. A 1380, 17-28 (2015)

Giannakaki, E., Van Zyl, P.G., Müller, D., Balis, D., Komppula, M.: Optical and microphysical characterization of aerosol layers over South Africa by means of multi-wavelength depolarization and Raman lidar measurements. Atmos. Chem. Phys. 16, 8109-8123 (2016). doi:10.5194/acp-16-8109-2016

Goldstein, A. H., Galbally, I. E.: Known and unexplored organic constituents in the Earth's atmosphere. Environ. Sci. Technol. 41(5), 1514-1521 (2007)

Government Gazette Republic of South Africa (14 October 2005) No. 28132. [Online] Available: http://www.info.gov.za/view/ [Accessed 16 October 2013).

Government Gazette Republic of South Africa. (4 May 2007) No. 29864. [Online] Available: http://www.info.gov.za/view/ [Accessed 16 October 2013).

Hobbs, P. V., Sinha, P., Yokelson, R. J., Christian, T. J., Blake, D. R., Gao, S., Kirchstetter, T.W., Novakov, T., Pilewski, P.: Evolution of gases and particles from a savanna fire in South Africa. J. Geophys. Res. Atmos. 108 (D13), 8485 (2003)

Hummel, J., Strehmel, N., Selbig, J., Walther, D., Kopka, J.: Decision tree supported substructure prediction of metabolites from GC-MS profiles. Metabolomics. 6, 322-333 (2010)

Jaars, K., Beukes, J.P., Van Zyl, P.G., Venter, A.D., Josipovic, M., Pienaar, J.J., Vakkari, V., Aaltonen, H., Laakso, H., Kulmala, M., Tiitta, P., Guenther, A., Hellén, H., Laakso L., Hakola, H.: Ambient aromatic hydrocarbon measurements at Welgegund, South Africa. Atmos. Chem. Phys. 14, 7075-7089 (2014). doi:10.5194/acp-14-7075-2014 
Jaars, K., Van Zyl, P.G., Beukes, J.P., Hellén, H., Vakkari, V., Josipovic, M., Venter A.D., Räsänen, et al., M., Knoetze, L., Cilliers, D.P., Siebert, S.J., Kulmala, M., Rinne, J., Guenther, A., Laakso, L., Hannele Hakola.: Measurements of biogenic volatile organic compounds at a grazed savannah grassland agricultural landscape in South Africa. Atmos. Chem. Phys. 16, 15665-15688 (2016). doi:10.5194/acp-16-15665-2016

Jimenez, J. L., Canagaratna, M. R., Donahue, N. M., Prevot, A. S. H., Zhang, Q., Kroll, J. H. et al.: Evolution of organic aerosols in the atmosphere. Science. 326, 1525-1529 (2009)

Kulmala, M., Asmi, A., Lappalainen, H. K., Baltensperger, U., Brenguier, J-L., Facchini, M. C. et al.: General overview: European Integrated project on Aerosol Cloud Climate and Air Quality interactions (EUCAARI) - integrating aerosol research from nano to global scales. Atmos. Chem. Phys. 11, 13061-13143 (2011). doi:10.5194/acp-11-13061-2011

Laakso, L., Vakkari, V., Virkkula, A., Laakso, H., Backman, J. Kulmala, M. et al.: South African EUCAARI measurements: seasonal variation of trace gases and aerosol optical properties. Atmos. Chem. Phys. 12, 1847-1864 (2012). doi:10.5194/acp-12-1847-2012

Lewis, A. C., Carslaw, N., Marriott, P. J., Kinghorn, R. M., Morrison, P., Lee, A. L., Bartle, K.D., Pilling, M.J.: A larger pool of ozone forming carbon compounds in urban atmospheres. Nature. 405, 778-781 (2000)

Lourens, A. S., Beukes, J. P., Van Zyl, P. G., Fourie, G.D., Burger, J.W., Pienaar, J.J., Read, C.E., Jordaan, J.H.L.: Spatial and Temporal assessment of Gaseous Pollutants in the Mpumalanga Highveld of South Africa. S. Afr. J. Sci. 107 (1/2), Art. \#269, 8 pages. (2011). doi: 10.4102/sajs.v107i1/2.269 269

Lourens, A. S. M., Butler, T. M., Beukes, J. P., Van Zyl, P. G., Beirle, S., Wagner, T., Heue, K-P., Pienaar, J.J., Fourie, G.D., Lawrence, M.G.: Re-evaluating the $\mathrm{NO}_{2}$ hotspot over the South African Highveld. S. Afr. J. Sci., 108(9/10), Art. \#1146, 6 pages (2012). doi: 10.4102/sajs. v108i11/12.1146

Özel, M. Z., Ward, M. W., Hamilton, J. F., Lewis, A. C., Raventos-Duran, T., Harrison, R. M.: Analysis of Organic Nitrogen Compounds in Urban Aerosol Samples Using GCxGC-TOF/MS. Aerosol. Sci. Technol. 44, 109-116 (2010) 
1 Petäjä, T., Vakkari, V., Pohja, T., Nieminen, T., Laakso, H., Aalto, P. P. Keronen, P., Siivola, E., Kerminen, V-M., Kulmala, M., Laakso, L.: Transportable aerosol characterization trailer with trace gas chemistry: design, instruments and verification. Aerosol Air Qual. Res. 13, 421-435 (2013)

Pope, C. A., Burnett, R. T.: Lung cancer, cardiopulmonary mortality and long-term exposure to fine particulate air pollution. JAMA 287 (9), 1132-1141 (2002)

Pretorius, I., Piketh, S., Burger, R.: Emissions management and health exposure: should all power stations be treated equal? Air Qual Atmos Health 11869 (2016)

Räsänen, M., Aurela, M., Vakkari, V., Beukes, J.P, Tuovinen, J.-P., Van Zyl, P.G., Josipovic, M., Venter, A.D., Jaars, K., Siebert, S.J., Laurila, T., Rinne, J., Laakso, L.: Carbon balance of a grazed savanna grassland ecosystem in South Africa, Biogeosciences 14, 1039-1054 (2017). www.biogeosciences.net/14/1039/2017/, doi:10.5194/bg-14-1039-2017

Ruiz-Jimenez, J., Parshintsev, J., Laitinen, T., Hartonen, K., Riekkola, M-L., Petäjä, T.Virkkula, A., Kulmala, M.: A complete methodology for the reliable collection, sample preparation, separation and determination of organic compounds in ultrafine $30 \mathrm{~nm}, 40 \mathrm{~nm}$ and $50 \mathrm{~nm}$ atmospheric aerosol particles. Anal. Methods 3, 2501-2509 (2011A)

Ruiz-Jimenez, J., Parshintsev, J., Laitinene, T., Hartonen, K., Riekkola, M., Petäjä, T. Kulmala, M.: Comprehensive two-dimensional gas chromatography, a valuable technique for screening and semiquantification of different chemical compounds in ultrafine $30 \mathrm{~nm}$ and $50 \mathrm{~nm}$ aerosol particles. J. Environ. Monit. 13, 2994-3003 (2011B)

Skoog, D.A., West, D.M., Holler, F.J., Crouch, S.R., Fundamentals of Analytical Chemistry, Ninth Edition, Brooks/Coles Cengage Learning, Belmont, CA, USA (2014)

South Africa Environmental Outlook. (2012). Chapter 5: Air Quality. [Online] Available: http://soer.deat.gov.za/dm_documents/Chapter_5_Air_Quality_4kp8X.pdf. [Accessed 13 March 2017].

Stein, A., Draxler, R. R., Rolph, G. D., Stunder, B. J., Cohen, M., Ngan, F.: NOAA’s HYSPLIT atmospheric transport and dispersion modeling system. B. Am. Meteorol. Soc. 96, 2059-2077 (2015) 
1 Strydom, S., Savage, M. J.: A spatio-temporal analysis of fires in South Africa. S. Afr. J. Sci. 112,

2

3

4

5

6 (11/12), 489 (2016)

Swap, R. J., Annegarn, H. J., Suttles, J. T., King, M. D., Platnick, S., Privette, J. L., Scholes, R.J.: Africa burning: A thematic analysis of the Southern African Regional Science Initiative (SAFARI 2000). J. Geophys. Res. Atmos. 108 (D13), 8465 (2003)

Tiitta, P., Vakkari, V., Josipovic, M., Croteau, P., Beukes, J. P., Van Zyl, P. G., Josipovic, M., Venter, A.D., Jaars, K., Pienaar, J.J., Ng, N.L., Canagaratna, M.R., Jayne, J.T., Kerminen, V.-M., Kokkola, H., Kulmala, M., Laaksonen, A., Worsnop, D.R., Laakso, L.: Chemical composition, main sources and temporal variability of PM1 aerosols in southern African grassland. Atmos. Chem. Phys. 14, 1909-1927 (2014). doi:10.5194/acp-14-1909-2014

Vakkari, V., Kerminen, V.-M., Beukes, J. P., Tiitta, P., Van Zyl, P. G., Josipovic, M. Venter, A.D., Jaars, K., Worsnop, D.R., Kulmala, M., Laakso, L.: Rapid changes in biomass burning aerosols by atmospheric oxidation. Geophys. Res. Lett. 41, 2644-2651 (2014). doi:10.1002/2014GL059396

Vakkari, V., Tiitta, P., Jaars, K., Croteau, P., Beukes, J.P., Josipovic, M., Kerminen, V-M., Kulmala, M., Venter, A.D., Van Zyl, P.G., Worsnop, D.R., Laakso, L.: Reevaluating the contribution of sulfuric acid and the origin of organic compounds in atmospheric nanoparticle growth. Geophys. Res. Lett. 42, 10486-10493 (2015). doi:10.1002/2015GL066459

Venter, A. D., Vakkari, V., Beukes, J. P., Van Zyl, P. G., Laakso, H., Mabaso, D. Tiitta, P., Josipovic, M., Kulmala, M., Pienaar, J.J., Laakso, L.: An air quality assessment in the industrialised western Bushveld Igneous Complex, South Africa. S. Afr. J. Sci. 108(9/10), Art. \#1059, 10 pages (2012). doi:10.4102/sajs. v108i9/10.1059

Venter, A.D., Van Zyl, P.G., Beukes, J.P., Josipovic, M., Jaars, K., Booyens, W., Vakkari, V., Laakso, L., Kulmala, M., Size-resolved characteristics of inorganic ionic species in atmospheric aerosols at a regional background site on the South African Highveld, J. Atmos. Chem. 75(3), 285-304 (2018). doi: 10.1007/s10874-018-9378-z

Welgegund, (2015). [Online] Available: http://www.welgegund.org/ [Accessed 25 June 2015]. 
1 Welthagen, W., Schnelle-Kreis, J., Zimmermann, R.: Search criteria and rules for comprehensive twodimensional gas chromatography-time-of-flight-mass spectrometry analysis of airborne particulate matter. J. Chromatogr. A 1019, 233-249 (2003)

4 Wichmann, J., Voyi, K. V. V.: Impact of cooking and heating fuel use on acute respiratory health of preschool children in South Africa. South Afr. J. Epidemiol. Infect. 21 (2), 48-54 (2006)

6 

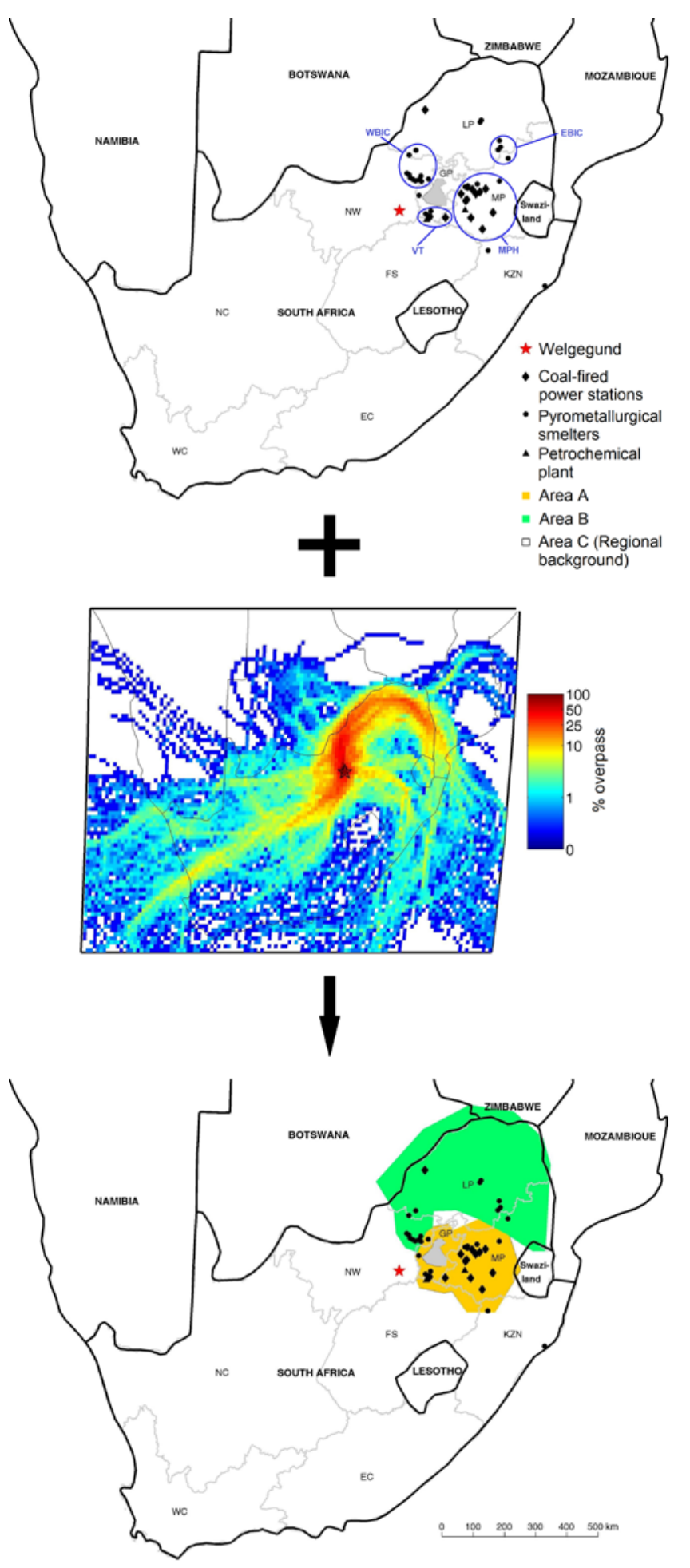

2 Fig. 1 Map of South Africa indicating the Welgegund measurement site, the major large point sources 3 in the north-eastern interior of South Africa, the source regions defined in this study and the 96-hour 4 overlay trajectories for the entire period. The colour scale for the overlay back trajectories indicates 5 the percentage of trajectories passing over $0.2^{\circ} \times 0.2^{\circ}$ grid cells, with blue to yellow to red indicating 6 the lowest to highest frequency of air mass movement 
(a)

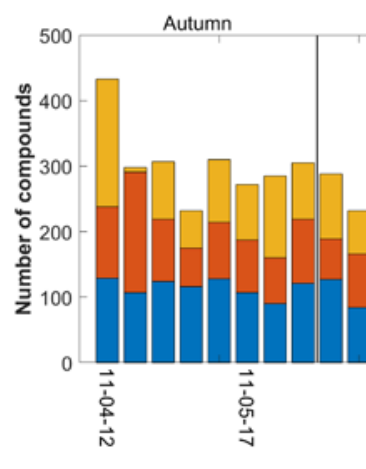

3

(b)

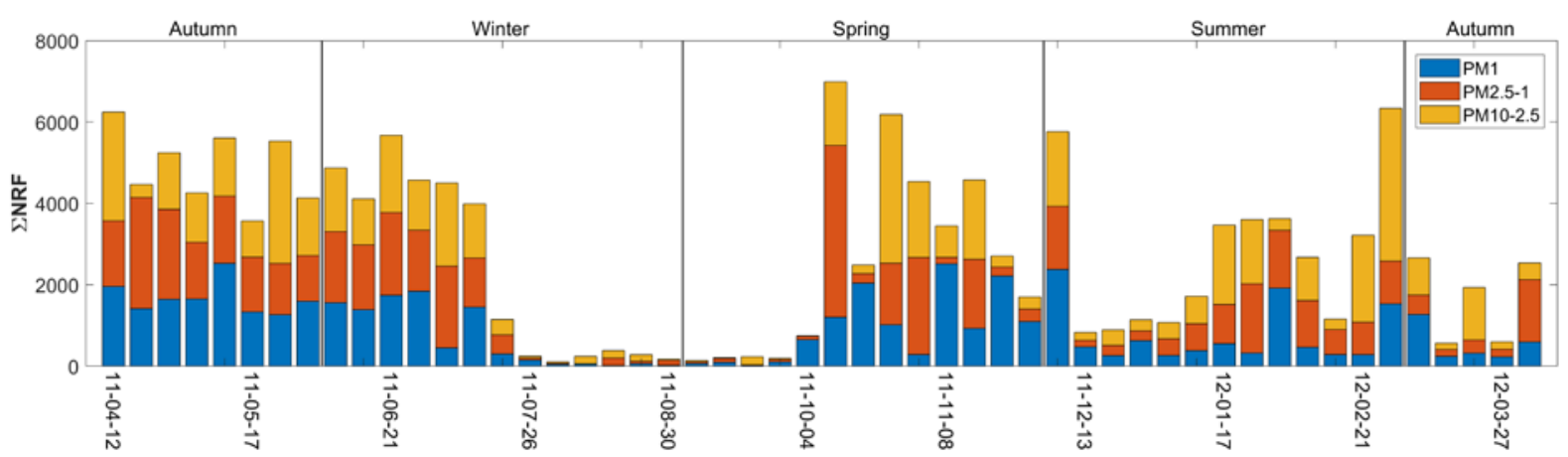

5

6 Fig. 2 (a) Total number of polar organic compounds identified and (b) the sum of the normalised 7 response factors ( $\left.\sum \mathrm{NRF}\right)$ for the three particle size ranges for each sample collected 
(a) Oxygenated species

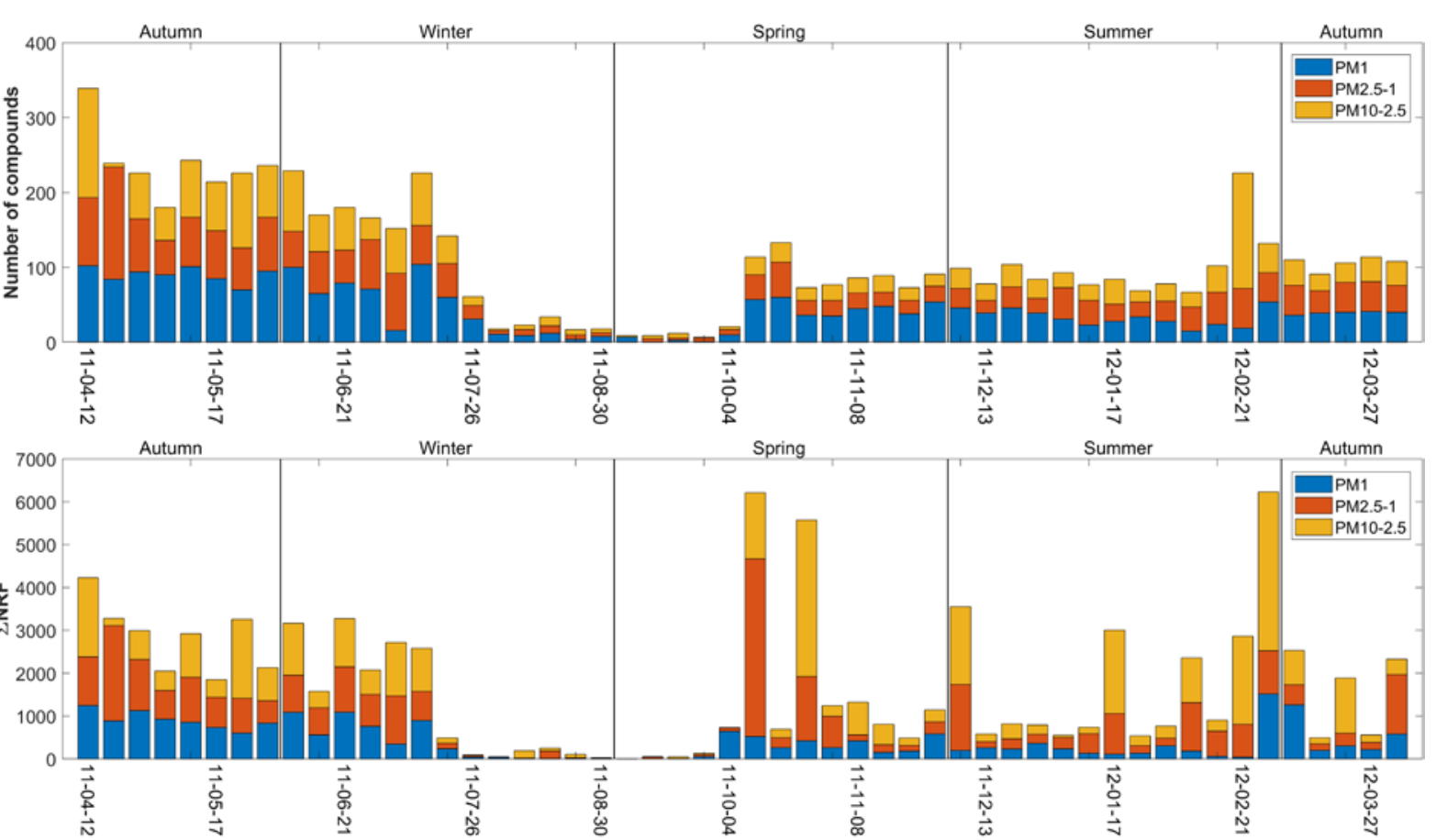

(b) Halogenated compounds
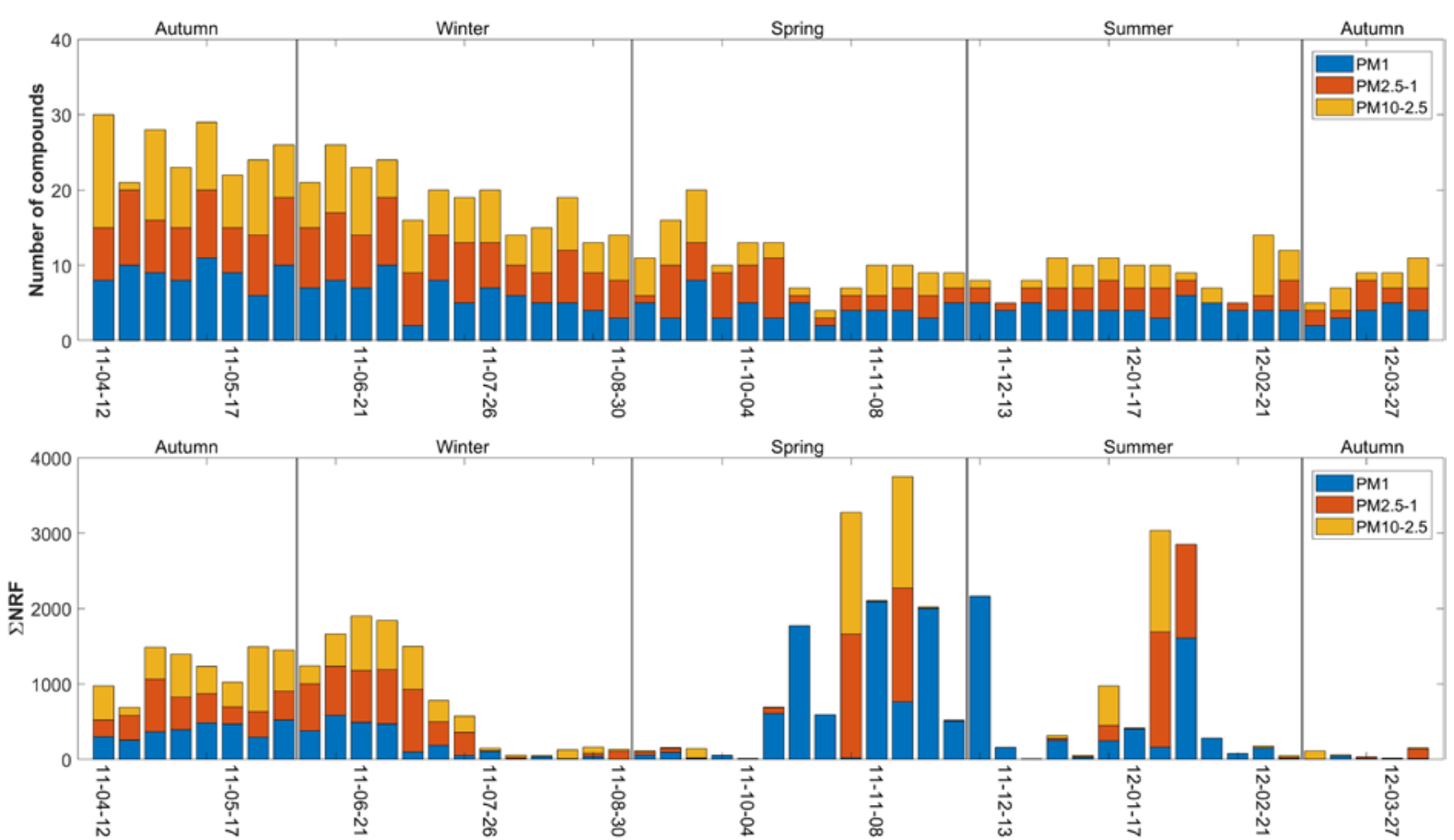

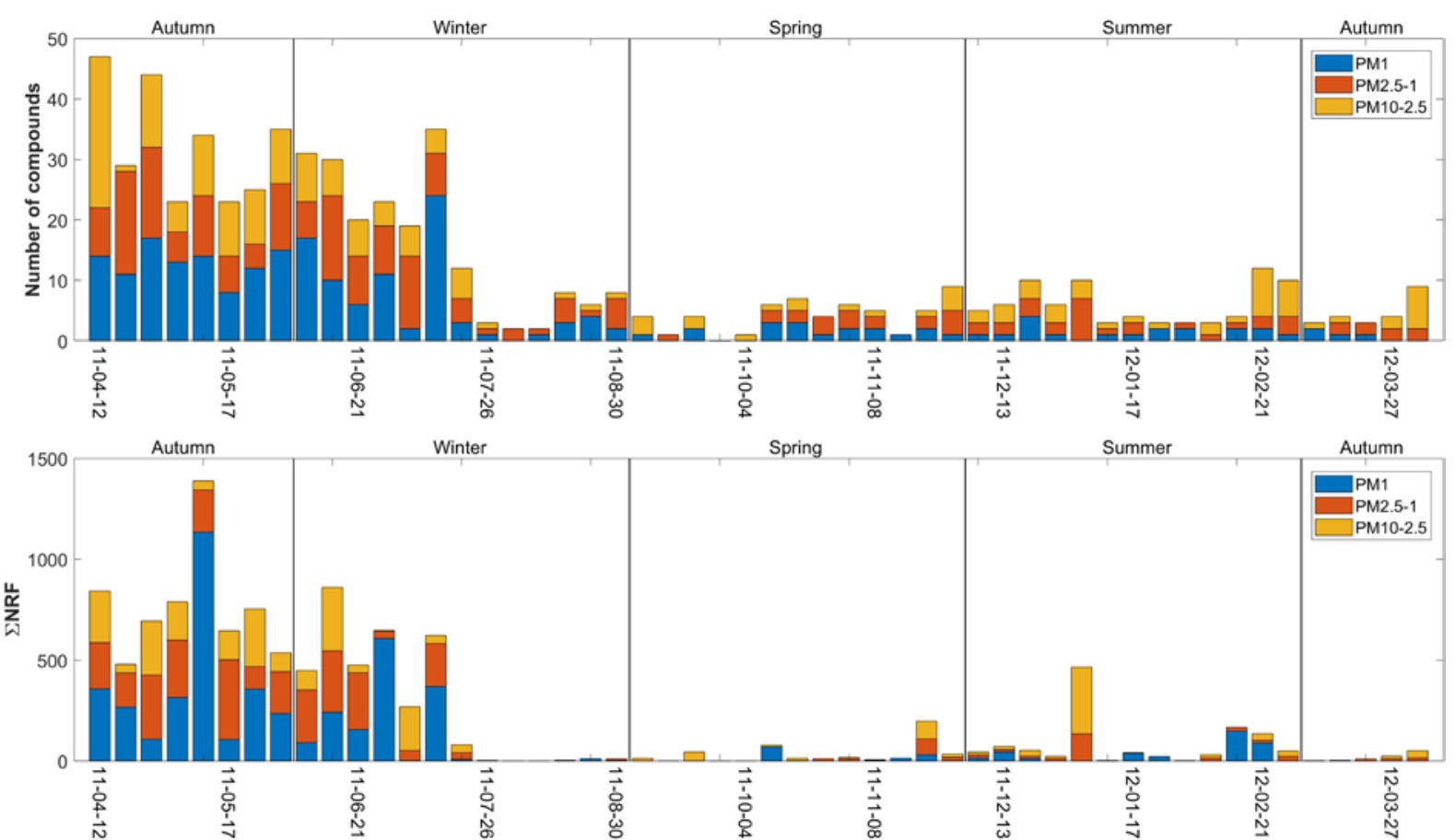

(d) S-containing species
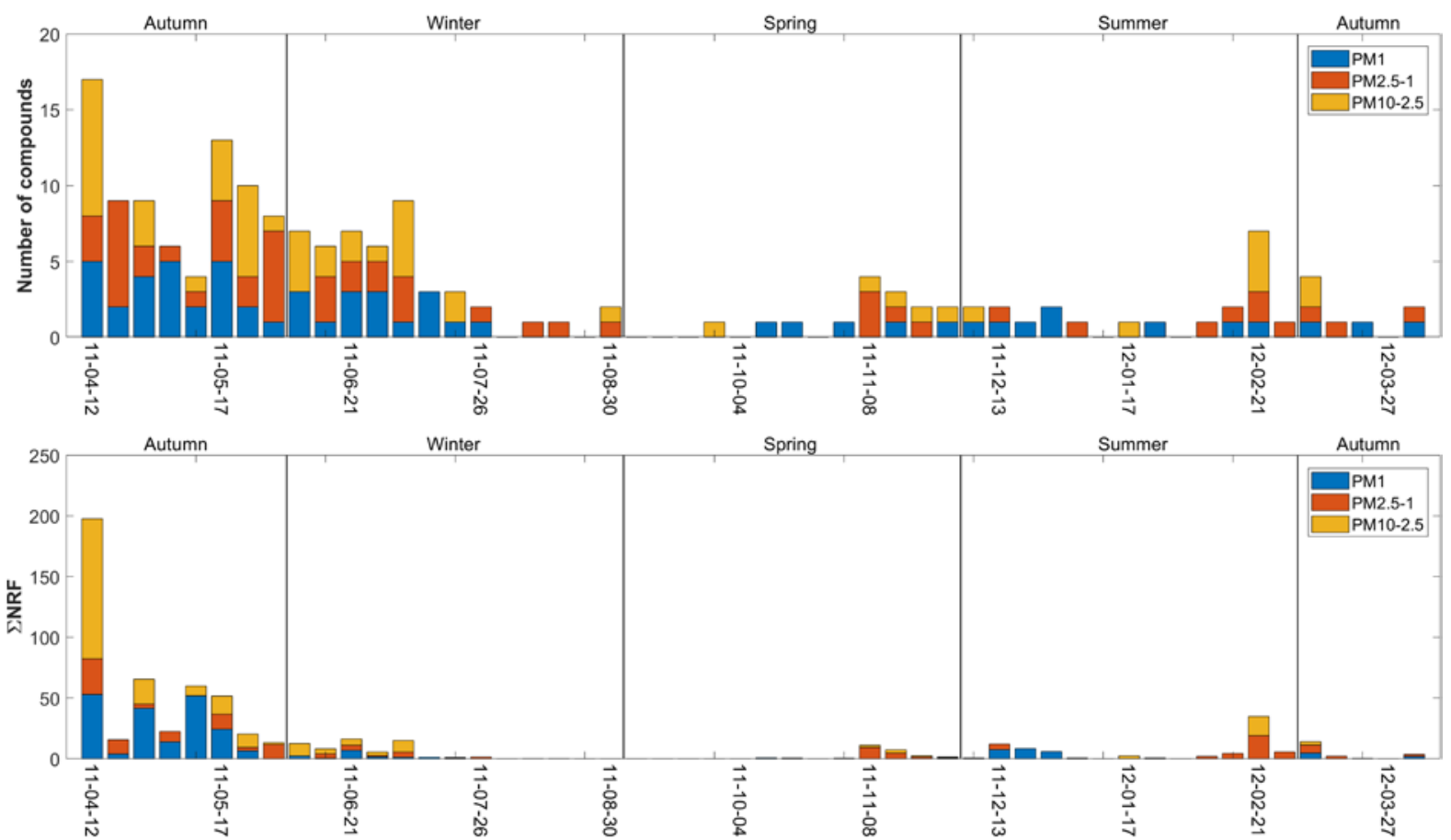

5

6 Fig. 3 The total number of (a) oxygenated species, (b) halogenated compounds, as well as (c) N- and

7 (d) S-containing compounds identified and the sum of the normalised response factors ( $\left.\sum \mathrm{NRF}\right)$ in the 8 three particle size ranges for each sample collected 
(a)

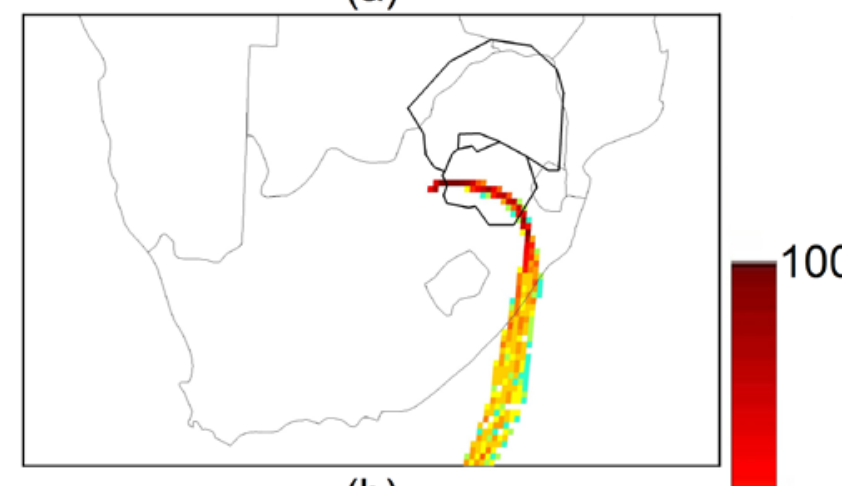

(b)

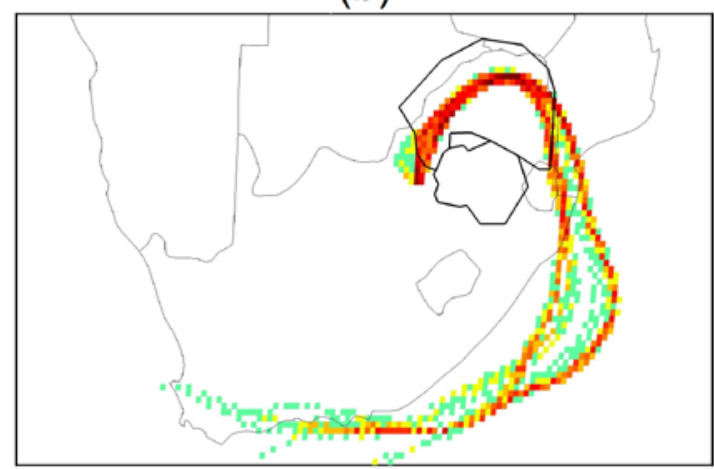

(c)

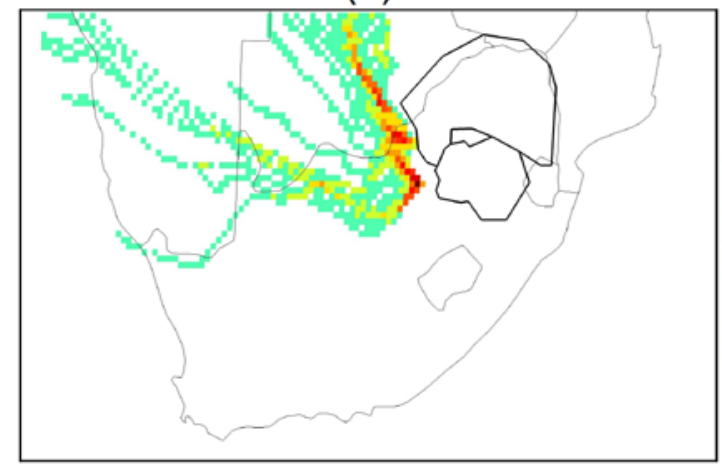

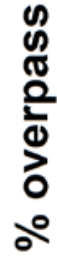

(d)

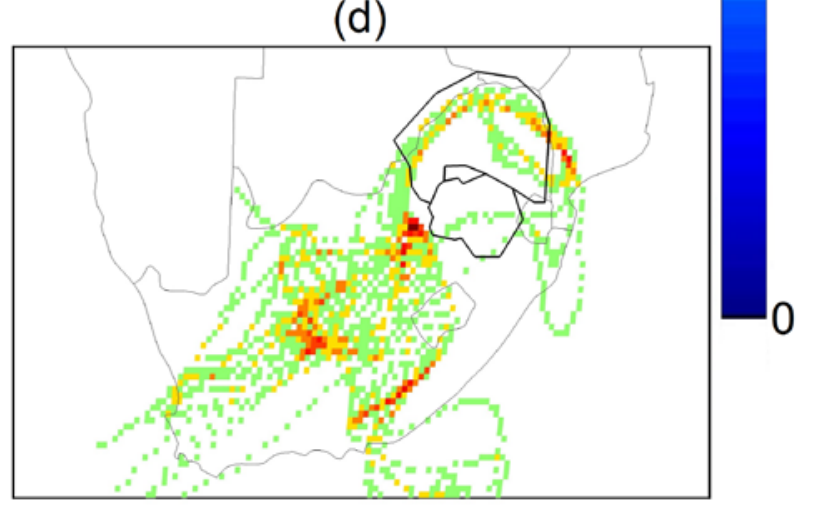

1

2 Fig. 4 Back trajectories of air masses passing over the defined source regions, i.e. (a) Area A, (b) Area

3 B and (c) Area C; (d) indicates back trajectories for air masses passing over different source regions.

4 The percentage of trajectories passing over $0.2^{\circ} \times 0.2^{\circ}$ grid cells are presented with colours, with red 5 the highest percentage 


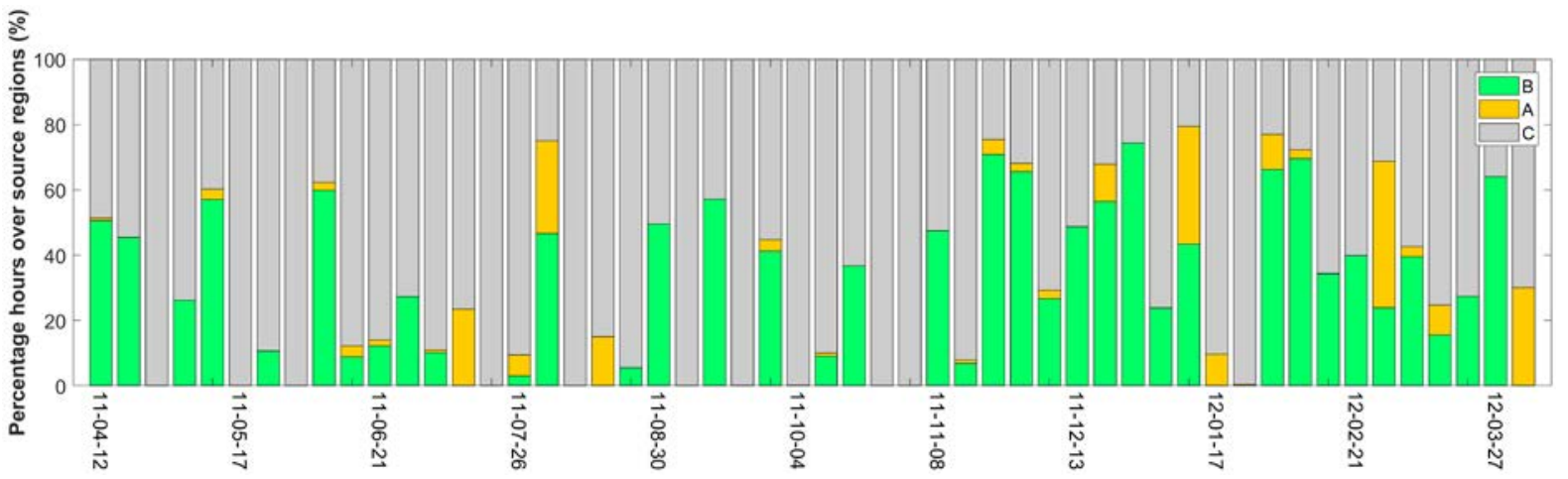

2 Fig. 5 Percentage of hourly back trajectories of air masses passing over source regions for each

3 sample collected with A, B and C representing Area A, Area B and Area C, respectively. 


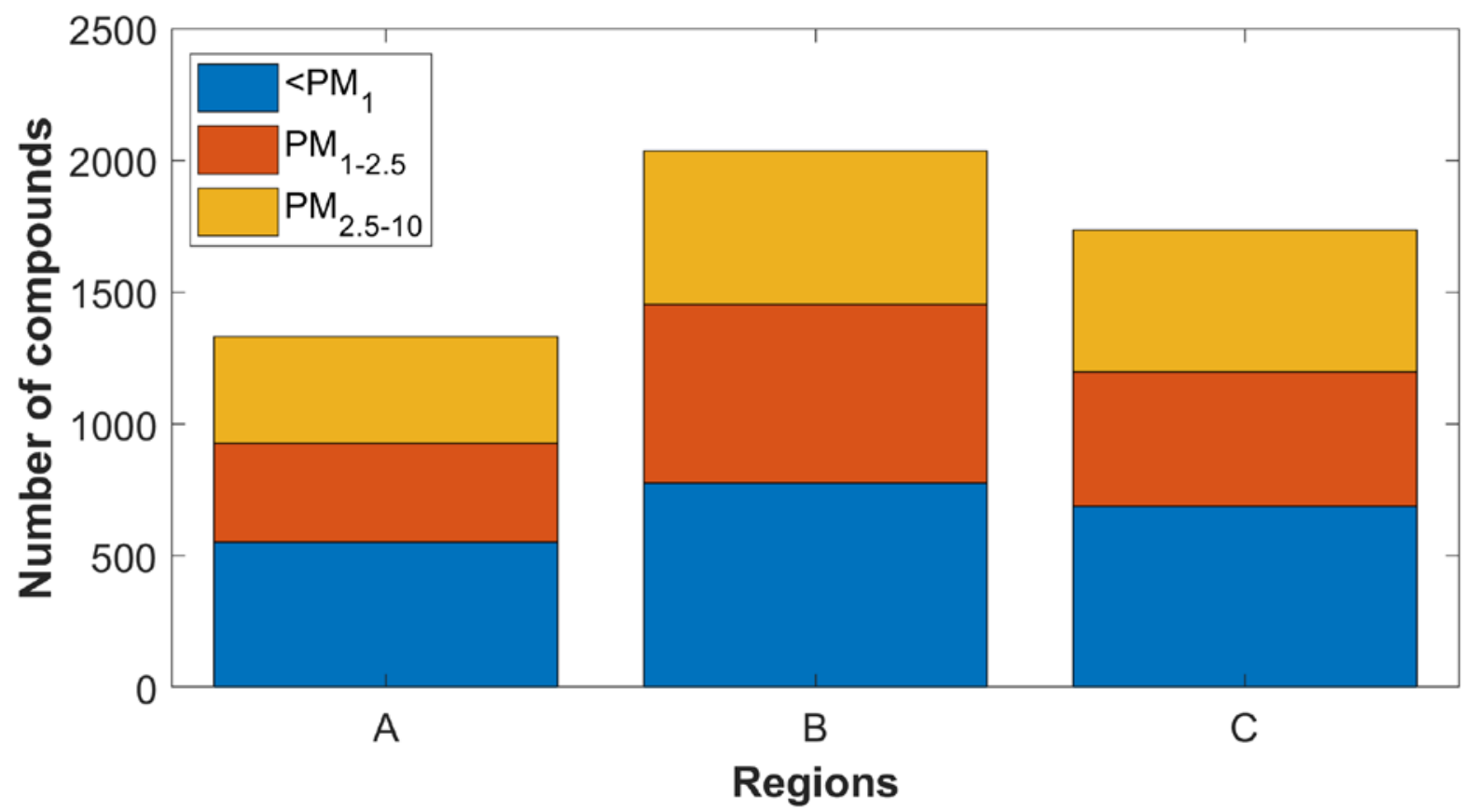

3

(b)

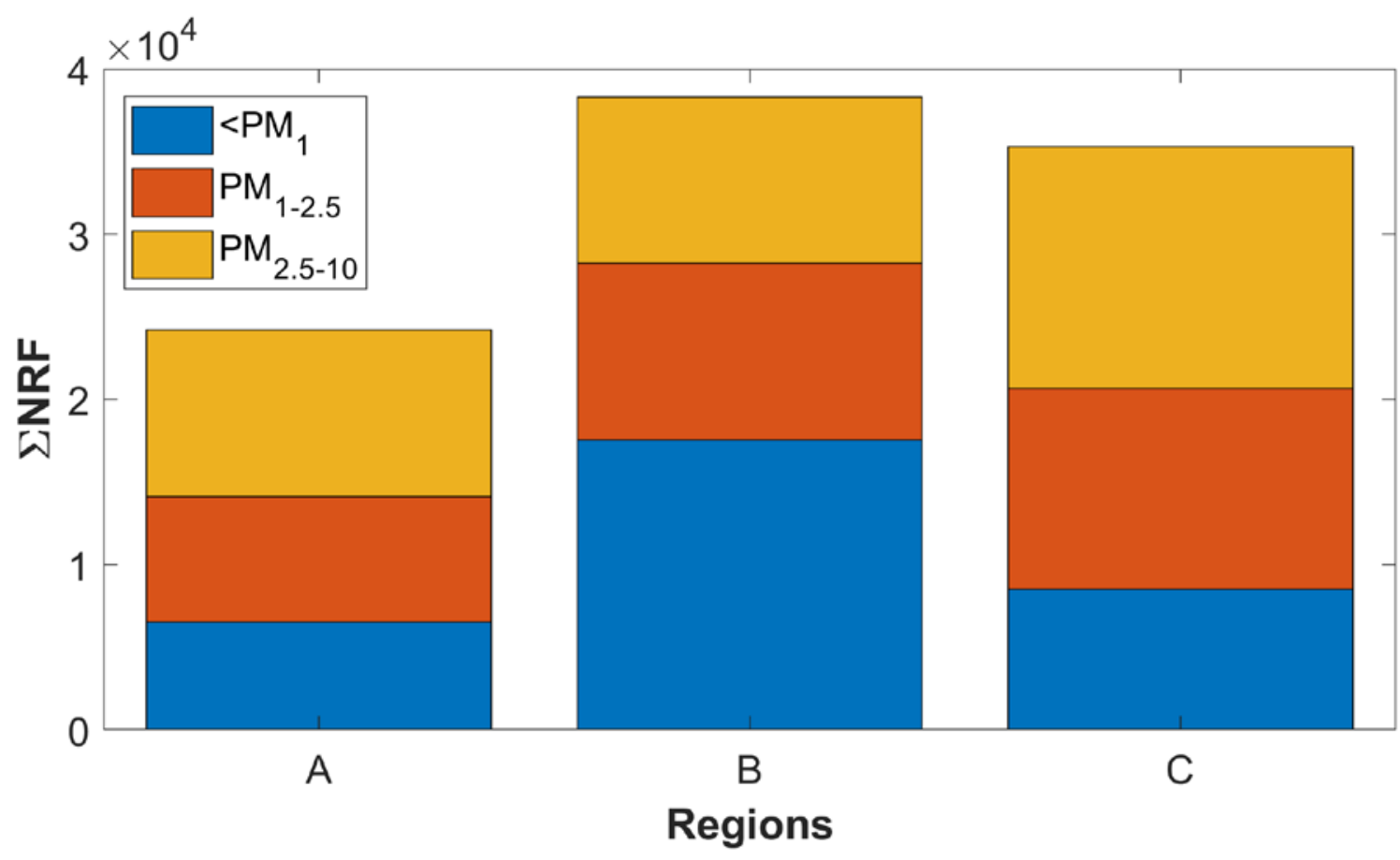

5

6 Fig. 6 (a) The total number of organic compounds and (b) the corresponding $\sum$ NRFs for each of the 7 defined source regions 

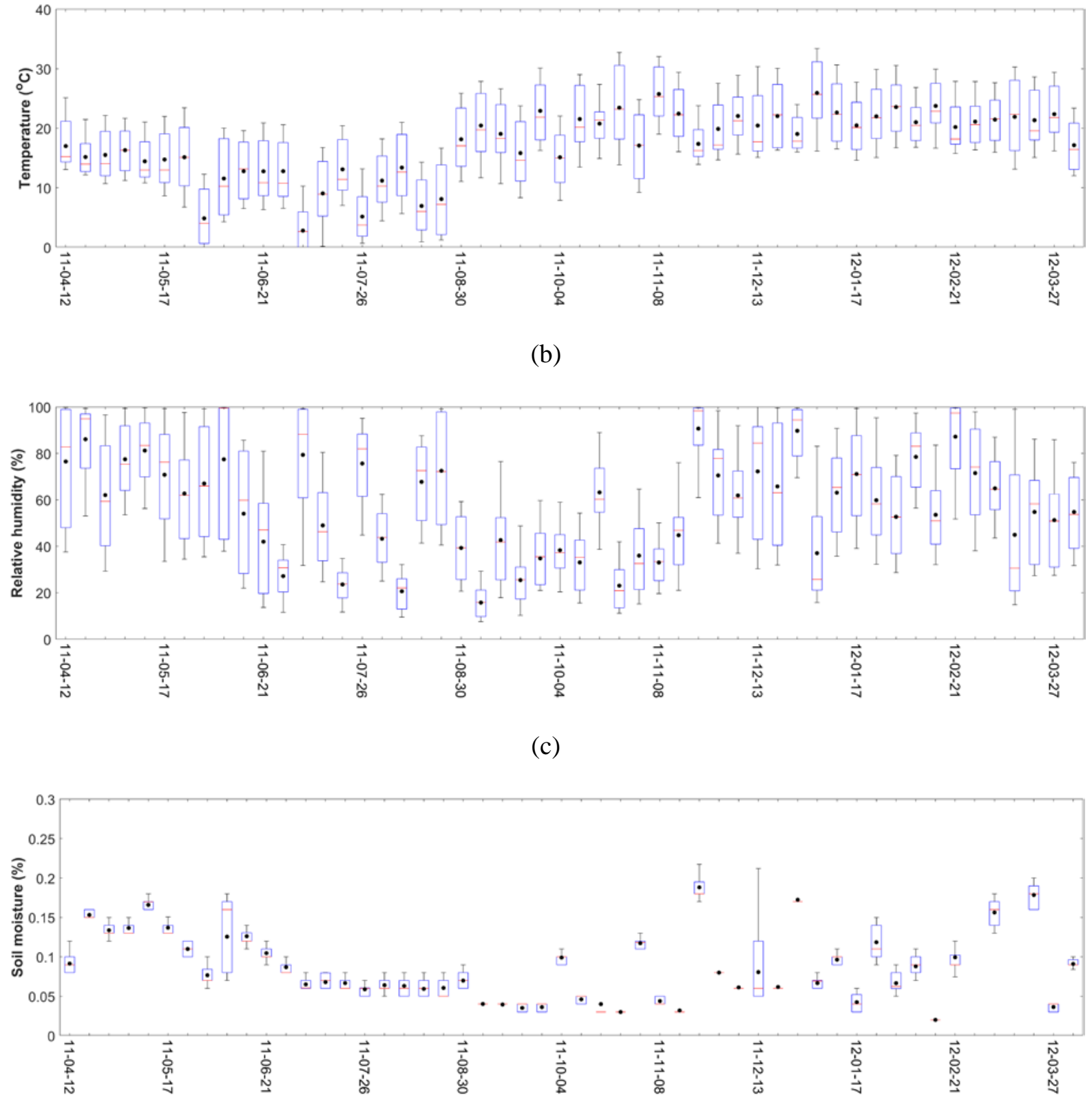

(d)

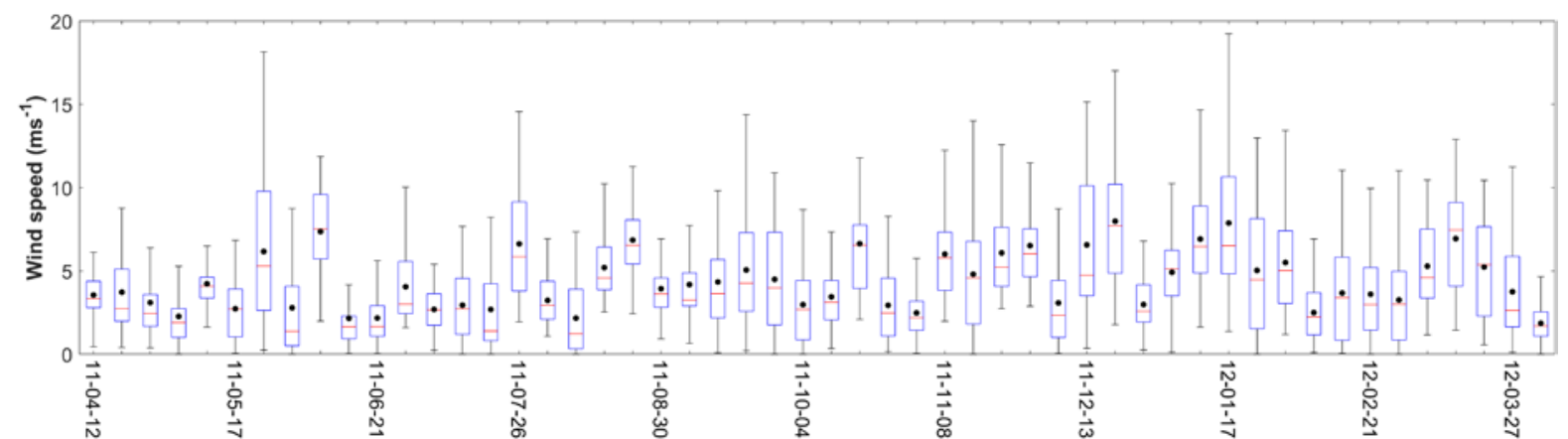


1 Fig. 7 Statistical spread of (a) temperature, (b) relative humidity, (c) soil moisture, and (d) wind speed 2 measured for each 24-hour sample for the entire sampling period. The red line of each box is the 3 median, the blue dots the mean, the top and bottom edges of the box the $25^{\text {th }}$ and $75^{\text {th }}$ percentiles and 4 the whiskers $\pm 2.7 \sigma(99.3 \%$ coverage if the data has a normal distribution) 


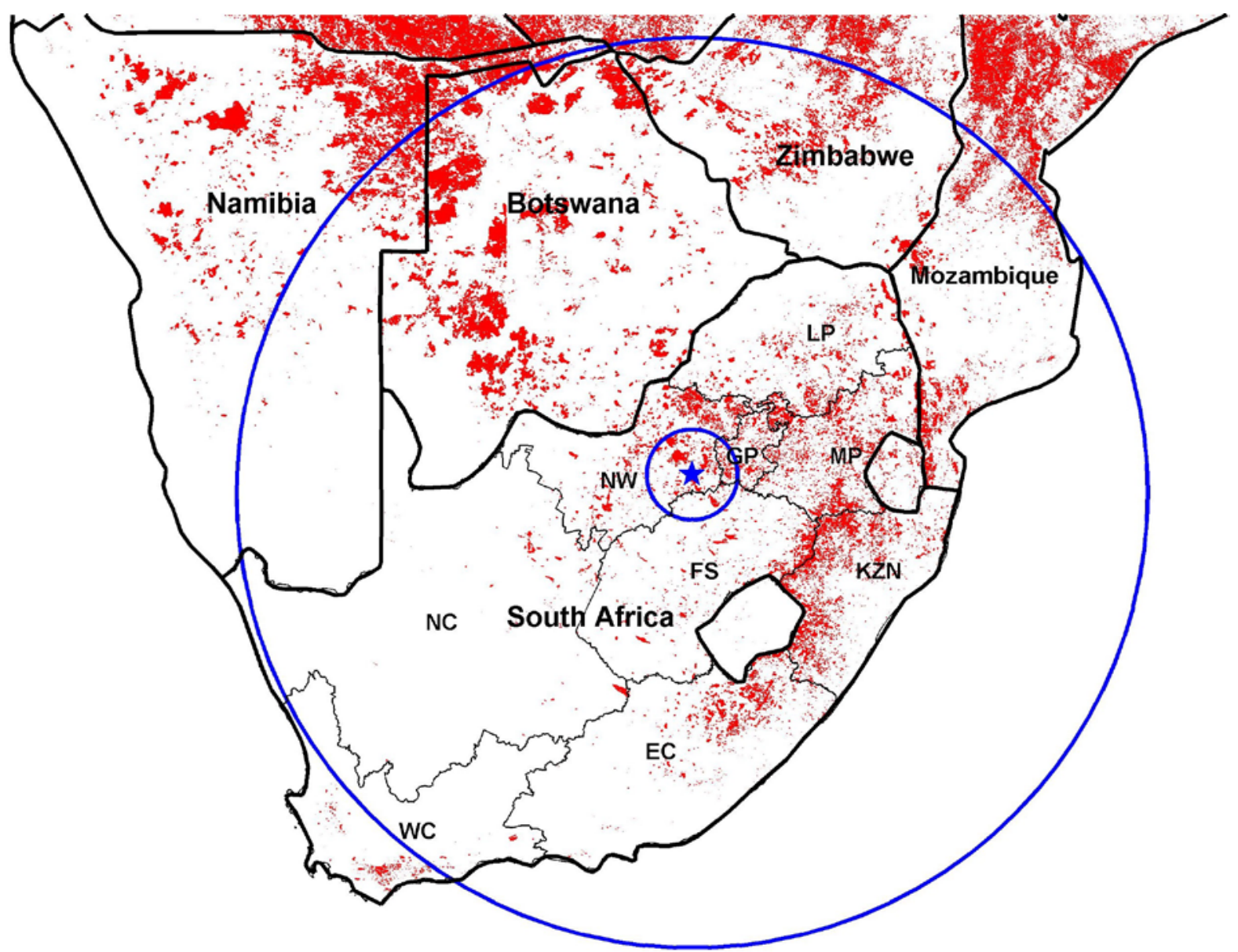

Fig. 8 Map of MODIS burned area observations in South Africa for the sampling period, with the blue circle the $100 \mathrm{~km}$ radius 


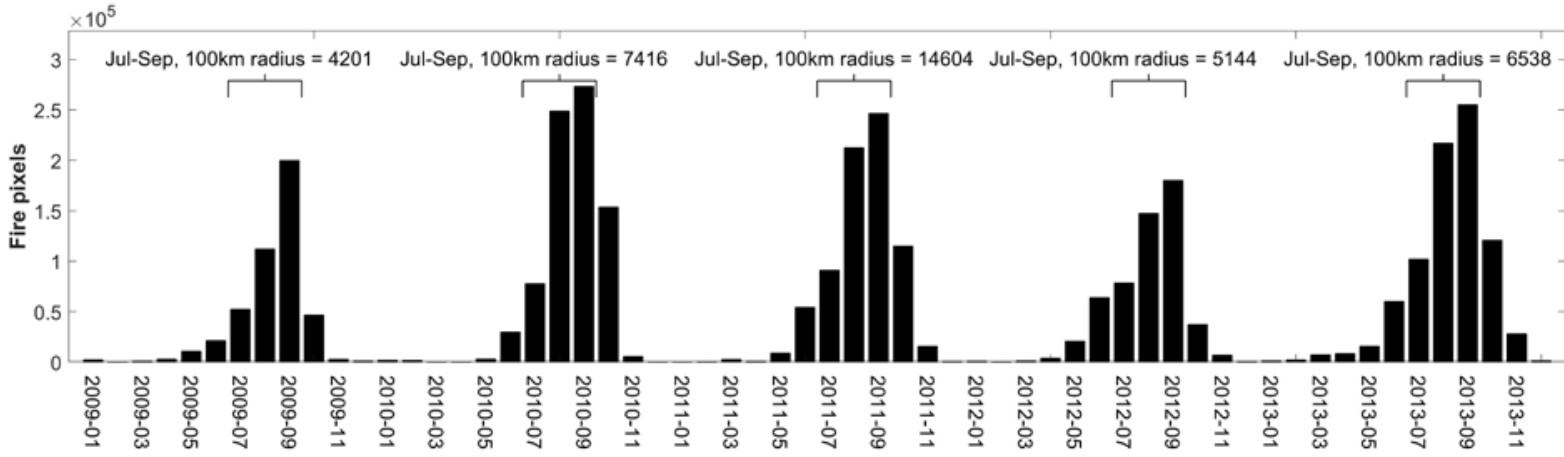

(b)

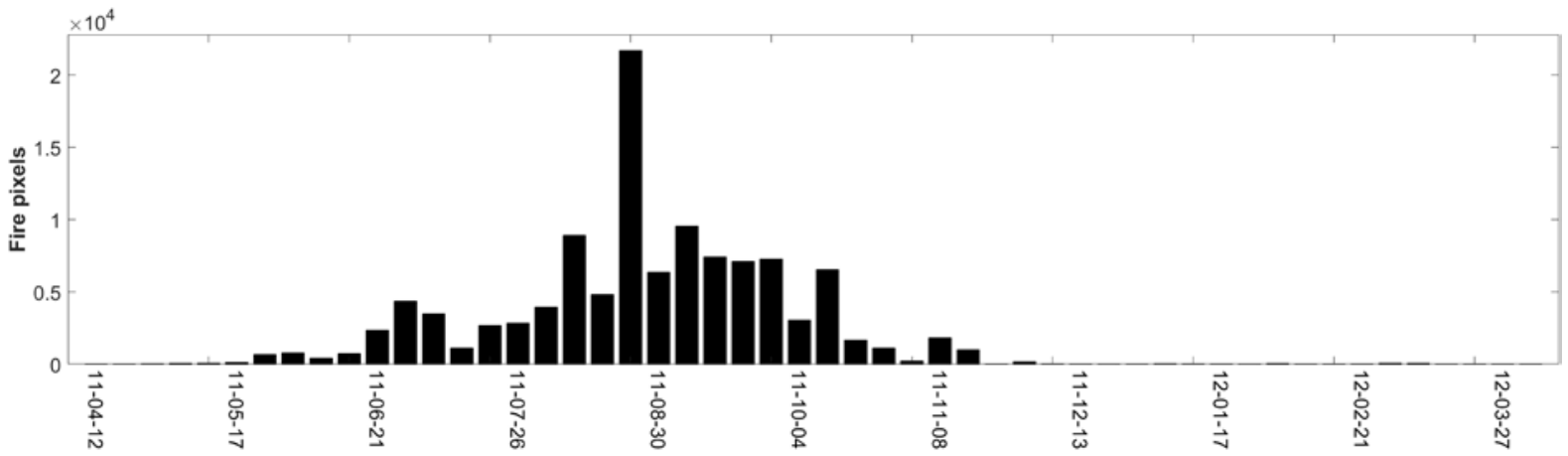

5

Fig. 9 Fire pixel counts representing the number of fires within a $1000 \mathrm{~km}$ radius from the Welgegund monitoring station (a) over a period of five years (2009 to 2013) and (b) for the entire sampling period 8 


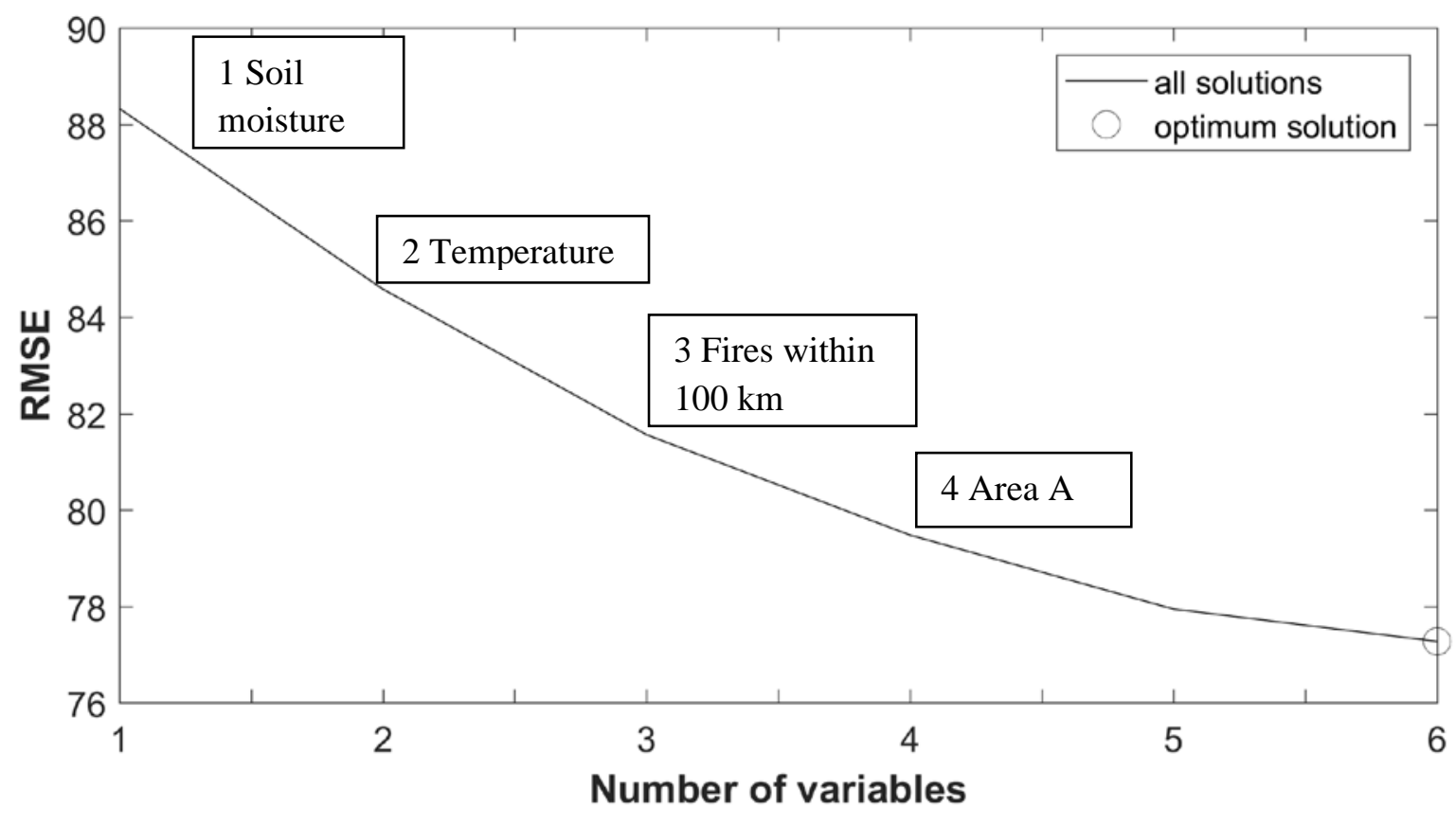

2

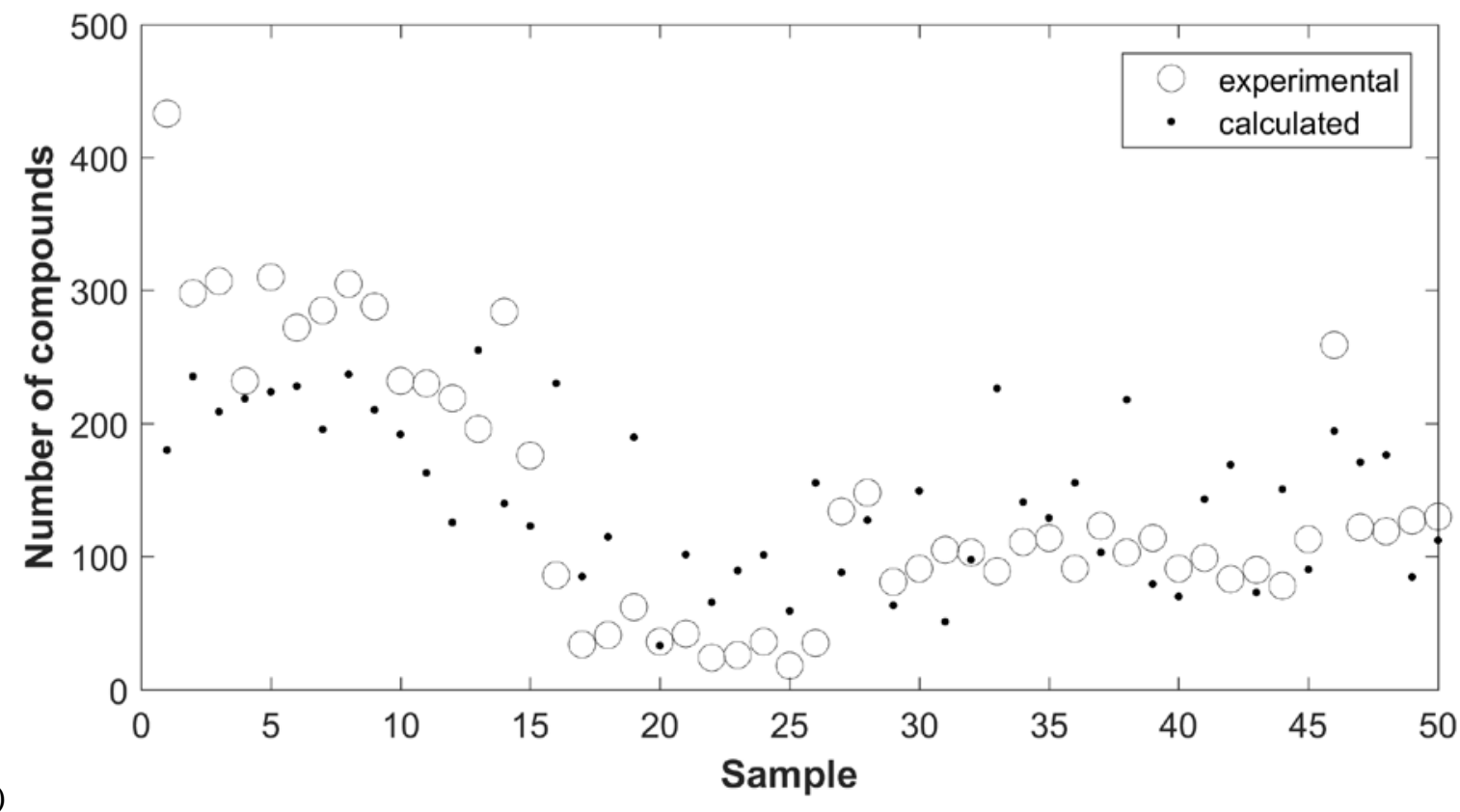

3 (b)

4

5 Fig. 10 (a) The optimum combination of independent variables to include in an MLR equation to 6 calculate the dependant variable (total number of organic compounds) indicated by the root mean 7 square error (RMSE) difference between the calculated and experimentally characterised total number 8 of organic compounds, and (b) comparison between total number of polar organic compound 9 calculated with MLR and experimentally characterised 
1 Table 1 The averages and standard deviations of the total number of species and their corresponding $\Sigma$ NRFs for each of the periods identified. Statistical

2 significance calculated with the t-test (Skoog et al., 2014) between the period with substantially lower total number of species and corresponding $\Sigma$ NRFs (2

3 August 2011 and 4 October 2011) and the two other periods are also presented

\begin{tabular}{|c|c|c|c|c|c|c|c|c|c|c|}
\hline & \multicolumn{2}{|c|}{ All polar organic compounds } & \multicolumn{2}{|c|}{ Oxygenated species } & \multicolumn{2}{|c|}{ Halogenated compounds } & \multicolumn{2}{|c|}{ N-containing compounds } & \multicolumn{2}{|c|}{ S-containing compounds } \\
\hline & $\begin{array}{c}\text { Total } \\
\text { number }\end{array}$ & $\Sigma$ NRFs & $\begin{array}{c}\text { Total } \\
\text { number }\end{array}$ & $\Sigma N R F s$ & Total number & $\Sigma \mathrm{NRFs}$ & $\begin{array}{c}\text { Total } \\
\text { number }\end{array}$ & $\Sigma$ NRFs & $\begin{array}{c}\text { Total } \\
\text { number }\end{array}$ & $\Sigma N R F s$ \\
\hline $\begin{array}{c}12 / 04 / 2011- \\
12 / 07 / 2011 \\
\end{array}$ & $278 \pm 58$ & $4769 \pm 777$ & $216 \pm 47$ & $2723 \pm 723$ & $24 \pm 4$ & $1335 \pm 366$ & $30 \pm 9$ & $675 \pm 264$ & $8 \pm 4$ & $36 \pm 51$ \\
\hline $\begin{array}{c}02 / 08 / 2011- \\
04 / 10 / 2011 \\
\end{array}$ & $35 \pm 12$ & $270 \pm 185$ & $17 \pm 8$ & $159 \pm 217$ & $15 \pm 3$ & $102 \pm 53$ & $4 \pm 3$ & $9 \pm 14$ & $1 \pm 1$ & $0 \pm 0$ \\
\hline $\begin{array}{c}11 / 10 / 2011- \\
04 / 04 / 2012 \\
\end{array}$ & $115 \pm 36$ & $2938 \pm 1870$ & $98 \pm 32$ & $1884 \pm 1793$ & $9 \pm 3$ & $989 \pm 1194$ & $6 \pm 3$ & $61 \pm 97$ & $2 \pm 2$ & $4.6 \pm 7$ \\
\hline $\begin{array}{c}\text { t-test for: } \\
\text { 12/04/2011 - } \\
\text { 12/07/2011 } \\
\text { and } \\
02 / 08 / 2011 \text { - } \\
04 / 10 / 2011\end{array}$ & $\begin{array}{c}\text { Significant } \\
\text { difference at } \\
80 \% \\
\text { probability }\end{array}$ & $\begin{array}{c}\text { Significant } \\
\text { difference at } \\
90 \% \\
\text { probability }\end{array}$ & $\begin{array}{c}\text { Significant } \\
\text { difference at } \\
80 \% \\
\text { probability }\end{array}$ & $\begin{array}{c}\text { Significant } \\
\text { difference at } \\
70 \% \\
\text { probability }\end{array}$ & $\begin{array}{l}\text { No significant } \\
\text { difference } \\
\text { even at } 50 \% \\
\text { probability - } \\
\text { values in } \\
\text { same range }\end{array}$ & $\begin{array}{c}\text { Significant } \\
\text { difference at } \\
70 \% \\
\text { probability }\end{array}$ & $\begin{array}{c}\text { Significant } \\
\text { difference at } \\
60 \% \\
\text { probability - } \\
\text { influence of } \\
\text { large pooled } \\
\text { STD }\end{array}$ & $\begin{array}{l}\text { Significant } \\
\text { difference } \\
\text { at } 60 \% \\
\text { probability } \\
\text { - influence } \\
\text { of large } \\
\text { pooled } \\
\text { STD }\end{array}$ & $\begin{array}{l}\text { Significant } \\
\text { difference } \\
\text { only at 50\% } \\
\text { probability - } \\
\text { due to large } \\
\text { pooled STD }\end{array}$ & $\begin{array}{c}\text { No } \\
\text { significant } \\
\text { difference } \\
\text { even at 50\% } \\
\text { probability - } \\
\text { due to large } \\
\text { pooled STD }\end{array}$ \\
\hline $\begin{array}{c}\text { t-test for: } \\
02 / 08 / 2011- \\
04 / 10 / 2011 \\
\text { and } \\
11 / 10 / 2011- \\
04 / 04 / 2012\end{array}$ & $\begin{array}{c}\text { Significant } \\
\text { difference at } \\
50 \% \\
\text { probability, } \\
\text { influenced } \\
\text { by large } \\
\text { pooled STD }\end{array}$ & $\begin{array}{c}\text { No } \\
\text { significant } \\
\text { difference } \\
\text { even at } 50 \% \\
\text { probability, } \\
\text { due to large } \\
\text { pooled STD }\end{array}$ & $\begin{array}{c}\text { Significant } \\
\text { difference at } \\
60 \% \\
\text { probability, } \\
\text { influenced } \\
\text { by large } \\
\text { pooled STD }\end{array}$ & $\begin{array}{c}\text { No } \\
\text { significant } \\
\text { difference } \\
\text { even at 50\% } \\
\text { probability, } \\
\text { due to large } \\
\text { pooled STD }\end{array}$ & $\begin{array}{l}\text { No significant } \\
\text { difference } \\
\text { even at 50\% } \\
\text { probability - } \\
\text { values in } \\
\text { same range }\end{array}$ & $\begin{array}{c}\text { No } \\
\text { significant } \\
\text { difference } \\
\text { even at } 50 \% \\
\text { probability, } \\
\text { due to large } \\
\text { pooled STD }\end{array}$ & $\begin{array}{c}\text { No } \\
\text { significant } \\
\text { difference } \\
\text { even at } 50 \% \\
\text { probability - } \\
\text { values in } \\
\text { same range }\end{array}$ & $\begin{array}{c}\text { No } \\
\text { significant } \\
\text { difference } \\
\text { even at } \\
50 \% \\
\text { probability } \\
\text { - values in } \\
\text { same range }\end{array}$ & $\begin{array}{c}\text { No } \\
\text { significant } \\
\text { difference } \\
\text { even at } 50 \% \\
\text { probability - } \\
\text { values in } \\
\text { same range }\end{array}$ & $\begin{array}{c}\text { No } \\
\text { significant } \\
\text { difference } \\
\text { even at 50\% } \\
\text { probability - } \\
\text { values in } \\
\text { same range }\end{array}$ \\
\hline
\end{tabular}

